\title{
The 4R's Framework of Nutritional Strategies for Post-Exercise Recovery: A Review with Emphasis on New Generation of Carbohydrates
}

\author{
Diego A. Bonilla ${ }^{1,2,3,4}$ (D), Alexandra Pérez-Idárraga ${ }^{1,5,6, *}$, Adrián Odriozola-Martínez ${ }^{4,7,8}$ and Richard \\ B. Kreider ${ }^{9}$ (D) \\ 1 Research Division, DBSS International SAS, Bogotá 110861, Colombia; dabonilla@dbss.pro \\ 2 Research Group in Biochemistry and Molecular Biology, Universidad Distrital Francisco José de Caldas, \\ Bogotá 110311, Colombia \\ 3 Research Group in Physical Activity, Sports and Health Sciences (GICAFS), Universidad de Córdoba, \\ Montería 230002, Colombia \\ 4 kDNA Genomics, Joxe Mari Korta Research Center, University of the Basque Country UPV/EHU, \\ 20018 Donostia-San Sebastián, Spain; adrianodriozola@gmail.com \\ 5 Move Nutrition, Medellín 050021, Colombia \\ 6 School of Medicine, Universidad de Antioquia, Medellín 050010, Colombia \\ 7 Sport Genomics Research Group, Department of Genetics, Physical Anthropology and Animal Physiology, \\ Faculty of Science and Technology, University of the Basque Country (UPV/EHU), 48940 Leioa, Spain \\ 8 Phymo Lab, Physiology and Molecular Laboratory, 08028 Barcelona, Spain \\ 9 Exercise \& Sport Nutrition Laboratory, Human Clinical Research Facility, Texas A\&M University, \\ College Station, TX 77843, USA; rbkreider@tamu.edu \\ * Correspondence: info.movenutrition@gmail.com; Tel.: +57-315-429-7105
}

check for

updates

Citation: Bonilla, D.A.;

Pérez-Idárraga, A.;

Odriozola-Martínez, A.; Kreider, R.B.

The 4R's Framework of Nutritional

Strategies for Post-Exercise Recovery:

A Review with Emphasis on New

Generation of Carbohydrates. Int. J.

Environ. Res. Public Health 2021, 18,

103. https://doi.org/10.3390/

ijerph18010103

Received: 5 December 2020

Accepted: 22 December 2020

Published: 25 December 2020

Publisher's Note: MDPI stays neutral with regard to jurisdictional claims in published maps and institutional affiliations.

Copyright: () 2020 by the authors. Licensee MDPI, Basel, Switzerland. This article is an open access article distributed under the terms and conditions of the Creative Commons Attribution (CC BY) license (https: / / creativecommons.org / licenses/by/4.0/).

\begin{abstract}
Post-exercise recovery is a broad term that refers to the restoration of training capacity. After training or competition, there is fatigue accumulation and a reduction in sports performance. In the hours and days following training, the body recovers and performance is expected to return to normal or improve. ScienceDirect, PubMed/MEDLINE, and Google Scholar databases were reviewed to identify studies and position declarations examining the relationship between nutrition and sports recovery. As an evidence-based framework, a 4R's approach to optimizing post-exercise recovery was identified: (i) Rehydration - a fundamental process that will depend on the athlete, environment and sports event; (ii) Refuel-the consumption of carbohydrates is not only important to replenish the glycogen reserves but also to contribute to the energy requirements for the immune system and tissue reparation. Several bioengineered carbohydrates were discussed but further research is needed; (iii) Repair-post-exercise ingestion of high-quality protein and creatine monohydrate benefit the tissue growth and repair; and (iv) Rest-pre-sleep nutrition has a restorative effect that facilitates the recovery of the musculoskeletal, endocrine, immune, and nervous systems. Nutritional consultancy based on the $4 \mathrm{R}^{\prime} \mathrm{s}$ is important for the wise stewardship of the hydration, feeding, and supplementation strategies to achieve a timely recovery.
\end{abstract}

Keywords: physiological adaptation; rehydration; carbohydrate conformation; protein synthesis; muscle soreness; sleep hygiene

\section{Introduction}

Physical exercise-induced adaptations take place as a result of acute-to-chronic changes at the metabolic, cellular, tissue, and system level [1-4]. During physical exercise, several molecular modifications are involved within the muscle cell processes of ATP synthesis and degradation [5], to the point that the relationship between energy production and consumption (myocellular ATP / ADP ratio) represents a key point in the occurrence of muscle fatigue, which is characterized by an acute reduction in force and power in response to contractile activity [6]. Here, the significant increase in the intramuscular concentration 
of inorganic phosphate $(\mathrm{Pi})$ and hydrogen ions $\left(\mathrm{H}^{+}\right)$is strongly correlated with the onset of neuromuscular fatigue [7].

Considering the allostasis model, which proposes that efficient regulation of a biological system requires anticipating needs and preparing to satisfy them before they arise [8], nutritional strategies after exercise helps to refuel energy sources (e.g., muscle and liver glycogen), replace fluid and electrolytes, synthesize new proteins to counteract both catabolic state and exercise-induced damage, and improve immune system response [9-11]. All these aspects have a tremendous influence on the allostatic response and the allostatic load, which must be sustained for an appropriate interval of time. According to Edes and Crews (2017), "Allostatic load results from altered physiology across multiple systems secondary to stressors and related responses and, therefore, may be estimated using multisystem biomarker composites representing, for example, the neuroendocrine, metabolic, cardiovascular, and immune systems" [12]. For example, during post-exercise molecular mechanisms that regulate the adaptation to exercise training, there is a time-course alteration in the protein content and enzyme activities as the result of the down-stream activation or inhibition of certain signaling pathways that regulate gene expression (transcription and translation processes) [13]. In the end, these mechanisms will result in an altered phenotype that is in line with the athlete's objectives, such as optimization in strength, cardiorespiratory fitness, power, agility, speed, exercise economy $\left(\mathrm{VO}_{2}\right.$ at submaximal velocity), body composition (i.e., muscle hypertrophy), among other aspects of sports performance (Figure 1).

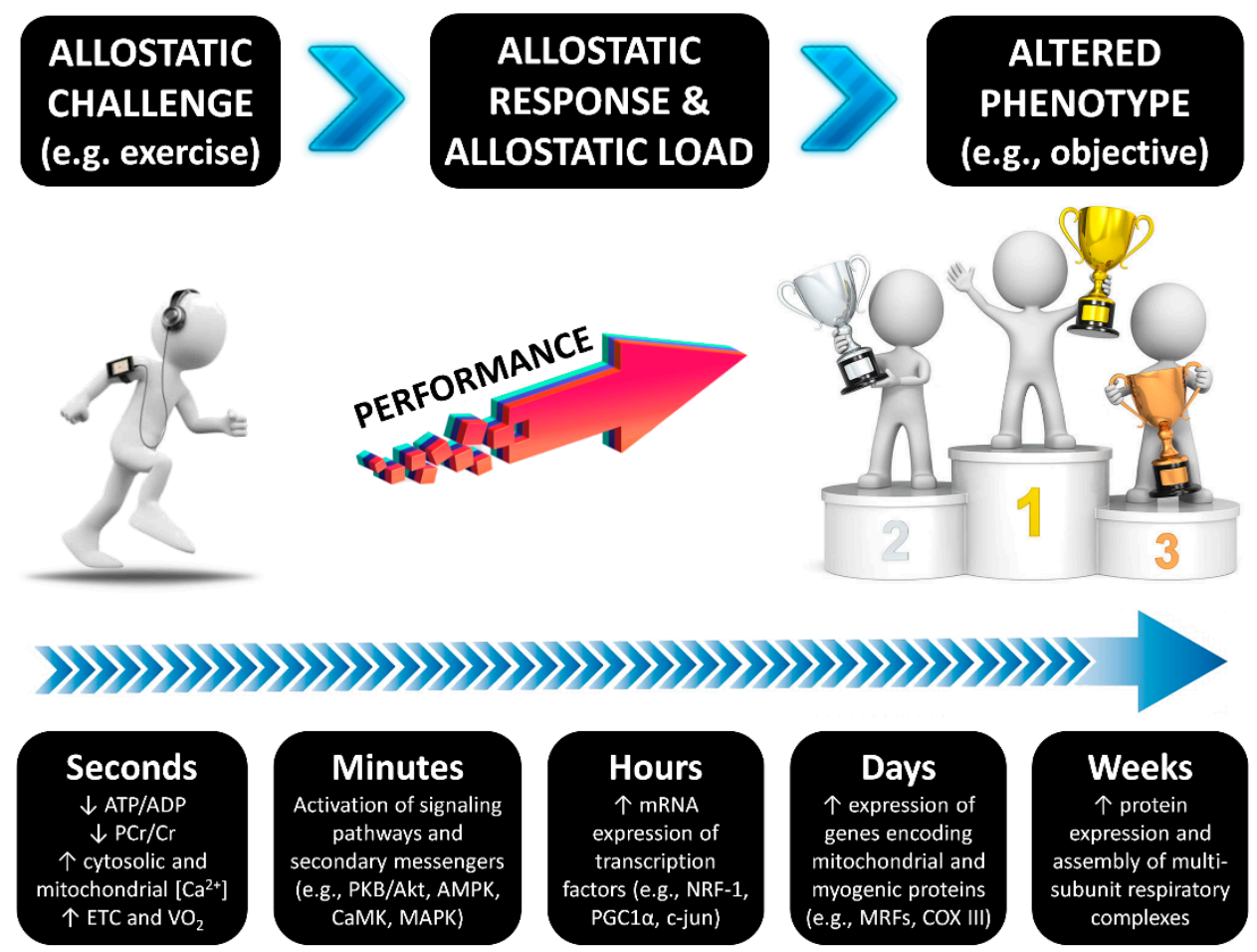

Figure 1. The time course of exercise-induced adaptations. Transient changes in metabolite sensing and signaling during/after exercise drive to gene transcription of early genes, myogenic regulators, genes of carbohydrate metabolism, lipid mobilization, transport and oxidation, mitochondrial metabolism and oxidative phosphorylation, and transcriptional regulators of gene expression and mitochondrial biogenesis [13]. DNA methylation is a regulatory point for transcription and may have a certain influence, although the current evidence suggest that exercise adaptations are regulated to a greater extent at the post-transcriptional level [14]. The time course changes following exercise have been described previously [15,16].

In this regard, the musculoskeletal tissue (as well as other tissues) possesses remarkable plasticity in response to repeated stimuli, such as exercise training, which results in phenotypic changes as an increase in the ability to sustain contraction and resist fatigue [14]. 
Therefore, to structure or periodize the recovery process, it is necessary to prepare the body physically and mentally to respond to the demands of training and competences, seeking not to interfere in the adaptation processes required to improve progressively [17]. Thus, recovery strategies will depend to a large extent on the proximity of the next session, the degree of physiological stress and the relevance of the next event. This determines how to rehydrate, replenish energy and consume the nutrients needed to improve tissue repair. This review article aims to summarize the nutritional strategies to optimize post-exercise recovery with emphasis on new carbohydrates forms.

\section{Methods}

A literature search using several databases (ScienceDirect, PubMed/MEDLINE, and Google Scholar) was conducted to identify studies and position declarations examining the relationship between nutrition strategies, dietary supplements and post-exercise recovery. The search string for all databases was "nutrition AND (exercise recovery OR sports recovery)" although further papers were sought by hand-searching. We prioritized papers written in English and published from 2010 onwards although selected publications before this cut-off were included as the basic body of evidence in the field. On the other hand, we excluded articles that did not analyze the effects on post-exercise recovery, abstracts or articles with no full-text version available, and studies focused on the effects of performance and image enhancing drugs. To emphasize in the description and role of new generation carbohydrates, the identification of additional studies was enriched by performing a handsearch with free language terms related to the effects of the administration of bioengineered carbohydrates on sports recovery and performance.

\section{Results and Discussion}

The execution of the search algorithm with Boolean operators resulted in 1816 references; nonetheless, we performed a screening of articles based on article type, text availability and suitability with the topic to discuss the following sections. To improve comprehension regarding the nutritional strategies that impact post-exercise recovery, a mnemonic entitled the $4 R^{\prime}$ s (Rehydrate, Refuel, Repair, and Rest) is introduced. This approach divides the nutrition intervention into four interrelated scenarios that follow the post-exercise time course in order to optimize the exercise-induced adaptations and recovery (Figure 2).

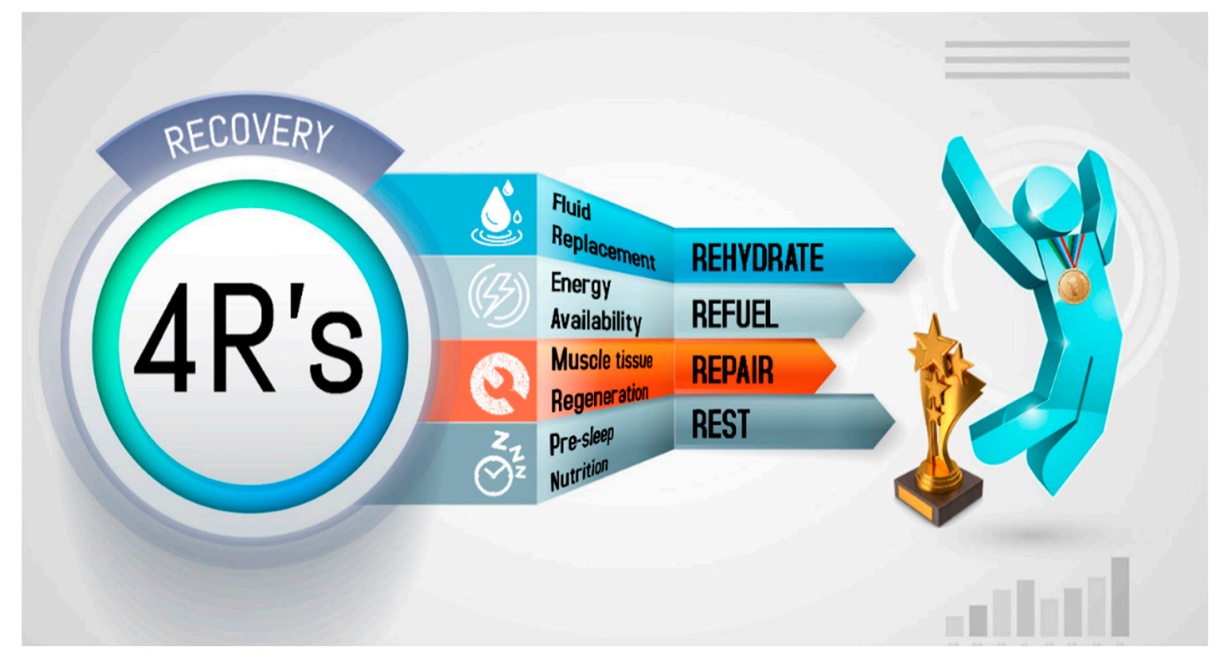

Figure 2. The $4 R^{\prime}$ s framework of nutritional strategies to optimize post-exercise recovery in athletes.

\subsection{Rehydrate}

One of the first goals during recovery is to replace any fluid and electrolyte deficits. Most physically active individuals sweat from 0.3 to $2.4 \mathrm{~L} \cdot \mathrm{h}^{-1}$, which depends on exercise in- 
tensity, duration, and environmental conditions such as altitude, heat, and humidity $[18,19]$. Moreover, individual characteristics (i.e., body mass, genetic predisposition, heat acclimatization state, physical fitness, and metabolic efficiency) might influence sweat rates for a given activity [20]. For instance, the highest sweat rate was registered at $3.7 \mathrm{~L} \cdot \mathrm{h}^{-1}$ for a world-class ultramarathon runner [21]. Thus, measuring pre and post-exercise body mass is a recommended practice to assess fluid status.

Rehydration is important, especially in team, endurance or ultra-endurance sports, where in many cases it is not possible to compensate for the loss of fluids and electrolytes that occur during exercise, particularly in hot and humid environments. As a general advise, for quick rehydration, it is recommended the consumption of $150 \%$ of the weight lost after exercise over a short recovery period (less than $4 \mathrm{~h}$ ) [22,23], with a sodium concentration between 20 and $30 \mathrm{mEq} \cdot \mathrm{L}^{-1}$ [18]. Athletes and practitioners should replenish three cups of fluid per pound of weight lost $\left(\sim 1.5 \mathrm{~L} \cdot \mathrm{kg}^{-1}\right)$ and to make sure body mass is back up before the next training session. Furthermore, it has even been shown that consuming a sodiumcontaining drink between 40 and $60 \mathrm{mEq} \cdot \mathrm{L}^{-1}$ can improve fluid retention and rehydration when there is little time between sessions or when there is moderate dehydration [24].

Rehydration can last between four and $24 \mathrm{~h}$ [9]. If recovery time and opportunities allow it, the consumption of sodium-rich foods, such as crackers, peanuts, bread, milk, cheese, ham, kabanos, and soups, may be sufficient to regain the state of euhydration. However, if the recovery time is less than $12 \mathrm{~h}$, more aggressive rehydration strategies and the use of moisturizing beverages (e.g., glycerol) are required before the next training or competition [25]. One practical application to improve both the rate of rehydration and total fluid retention following exercise is the ingestion of glycerol [22,26]; however, professional advice is recommended to avoid potential gastrointestinal discomfort with any hyperhydration agent.

In the rehydration process, it has been found that neither the addition of potassium to the drink [27] nor the way of distributing the volume [28] nor the temperature influence the percentage of liquid preserved to be subsequently used by the body for rehydration [29]; however, it is believed that the delay in early rehydration after exercise is attributed to a reduction in sensations associated with thirst, and it is known that the taste and cool temperature of beverages can positively affect these sensations [30]. On the other hand, some drinks that can be used for rehydration and in turn help recovery has been successfully studied, such as chocolate milk [31-33].

Rehydration is a fundamental step in recovery, but what, how, when and how much will depend on the athlete and the particular event. We adhere to the position statement of the National Athletic Trainers' Association to emphasize that education strategies for athletes should address personal sweat rates, hydration cues, and rehydration strategies that avoid both hypohydration and fluid overload [23].

\subsection{Refuel}

At the end of the exercise, there are several strategies to maximize muscle and liver glycogen replenishment, especially when two or more sessions are performed on the same day or when competing on consecutive days. For planning, it is necessary to consider the state of training, schedules, and the magnitude of the depletion of reserves, besides the type of exercise [34]. In this sense, the amount of carbohydrates is determined by the need to replenish muscle glycogen stores, and according to Jeukendrup (2017) [17], this is closely related to:

- Time to next training session or competition,

- Nutrition periodization to achieve adaptations,

- Need for muscle repair and growth,

- The amount consumed before and after as part of global requirements.

Although certain general recommendations can be given, the carbohydrate intake must be fine-tuned based on individual features, total energy daily expenditure, exercise training requirements, and the respective feedback from training performance in daily 
recovery [35]. In athletes with high body mass (e.g., basketball and rugby) or players under a weight loss program it might be better to reduce the energy intake to the needs of the previous category [36]. Additionally, resistance/power athletes do not need much carbohydrates as endurance athletes to maintain optimal liver and muscle glycogen; therefore, based on the exercise and sports nutrition review update of the International Society of Sports Nutrition [37], daily carbohydrate needs might be ranked as follows:

- Moderate duration/low-intensity training (e.g., 2-3 h per day of intense exercise performed 5-6 times per week): $5-8 \mathrm{~g} \cdot \mathrm{kg}^{-1}$ body mass $\cdot$ day $^{-1}$

- Moderate to heavy endurance training (e.g., 3-6 h per day of intense training in 1-2 daily workouts for $5-6$ days per week): $8-10 \mathrm{~g} \cdot \mathrm{kg}^{-1}$ body mass $\cdot$ day $^{-1}$

- Extreme exercise programs or competition $(+6 \mathrm{~h}$ per day or high competition frequency during the week): $10-12+\mathrm{g} \cdot \mathrm{kg}^{-1}$ body mass $\cdot$ day $^{-1}$

Moreover, in the post-exercise period, it takes about four hours for carbohydrates to be digested and absorbed into muscle and liver tissues to be incorporated as glycogen. Hence, if rapid recovery is required due to a limited time period available, the priority should be to consume large amounts of daily carbohydrates $\left(>8 \mathrm{~g} \cdot \mathrm{kg}^{-1}\right.$ body mass $\cdot$ day $\left.^{-1}\right)$ and to eat a high carbohydrate meal within two hours following exercise with at least $1.2 \mathrm{~g} \cdot \mathrm{kg}^{-1} \cdot \mathrm{h}^{-1}$ for the first four hours of recovery [38]. Ingestion of a glucose polymer or the combination of glucose and fructose (sucrose) results in a fast replenishment of muscle glycogen stores whilst also minimizing gastrointestinal distress [39], and there is no need for protein and/or amino acid ingestion in order to enhance the insulin levels if sufficient carbohydrates are consumed $\left(1.2 \mathrm{~g} \cdot \mathrm{kg}^{-1} \cdot \mathrm{h}^{-1}\right)$. In fact, higher insulin concentrations do not further increase the rate of muscle glycogen synthesis when carbohydrate intake is sufficient [34]. Slightly less carbohydrate plus protein (e.g., $1 \mathrm{~g}$ carbohydrate $\cdot \mathrm{kg}^{-1}$ and $0.5 \mathrm{~g}$ protein $\cdot \mathrm{kg}^{-1}$ ) within $30 \mathrm{~min}$ after exercise or carbohydrates along with caffeine may also be used to aid rapid glycogen resynthesis [37]. Additionally, compared to carbohydrate ingestion alone, multiday supplementation with creatine monohydrate along with an adequate amount of carbohydrates has been reported to have a higher positive impact on muscle glycogen synthesis [40].

The consumption of carbohydrates is not only important to replenish the reserves, but also to contribute to cover the energy requirements that are fundamental to help the competition of the immune system and the repair of the tissues [35]. Sports nutritionists, coaches and athletes should be cautious with the potential physiological implications of the relative energy deficiency in sport, which includes impaired metabolic rate, hormonal disruptions, menstrual dysfunction, reduced bone health, immunity, protein synthesis, and cardiovascular health [41,42].

Considering the potential impact of the type of carbohydrates on performance and recovery, some bioengineered formulations with different physicochemical characteristics are described in the next lines. These bioengineering processes refer to the application of theoretical and experimental methods of the basic sciences to produce new scientific knowledge with practical applications, such as the modification of the chemical structure of a molecule by means of biotechnological procedures that use microorganisms (e.g., bacteria) in order to produce substances with different metabolic responses since they are not found regularly in food. We recommend the reader to visit the Carbohydrate Structure Database (CSDB, http:/ / csdb.glycoscience.ru) [43] and the database of Chemical Entities of Biological Interest (ChEBI) [44] to know in depth about advances, structures and different applications of the new generation of carbohydrates produced through different processes and that are of biological interest.

\subsubsection{Isomaltulose (BCSDB ID: 111249; ChEBI 18394)}

Commercially known as Palatinose ${ }^{\mathrm{TM}}, 6$-O- $\alpha$-D-glucopyranosyl-D-fructose (or isomaltulose) is a white and sweet disaccharide constituted of glucose and fructose that originates from an enzymatic rearrangement of the $\alpha-(1 \rightarrow 2)$ bond of sucrose until the formation of an $\alpha-(1 \rightarrow 6)$ bond by microbial sucrose isomerases (i.e., EC 5.4.99.11) [45]. Thus, isomaltulose 
is part of a category of carbohydrates called non-starch slowly digestible carbohydrates, which have unique glycosidic bonds that are different from the better-known or naturally occurring molecules; therefore, they are digested and absorbed at a different rate resulting in a changed glycemic and insulinemic response [46]. Evidence suggests that the use of isomaltulose instead of conventional sucrose has certain metabolic advantages that might be useful for metabolic syndrome patients [47], besides being an interesting ingredient for the development of "tooth-friendly" confectionery [48]. For instance, positive metabolic effects have been reported in physically-active type-I diabetic patients given that the consumption of isomaltulose alongside rapid-acting insulin reduction improved blood glucose responses to exercise and produced a similar high-intensity run performance compared with dextrose [49].

At a sporting level, isomaltulose ingestion $(750 \mathrm{~mL}, 10 \% w / v)$ maintained a more stable blood glucose concentration and increased fat oxidation during exercise, resulting in improved cycling performance compared to maltodextrin consumption in endurancetrained athletes $\left(\mathrm{VO}_{2 \max }>55 \mathrm{~mL} \cdot \mathrm{kg}^{-1} \cdot \mathrm{min}^{-1}\right)$ [50]. According to the authors, these results could be explained by the slower availability and low glycemic properties of isomaltulose, which allowed a greater reliance on lipid metabolism and might spare glycogen utilization during endurance exercise training. Similar results on fat oxidation during incremental exercise on cycle ergometer have been found recently in Japanese athletic population (long distance runners and triathletes) after isomaltulose ingestion $(500 \mathrm{~mL}, 8 \%)$ [51]. In addition, after a soccer match simulation between male college soccer players, Stevenson et al. (2017) reported that the consumption of an $8 \%$ isomaltulose drink $\left(0.36 \mathrm{~mL} \mathrm{~kg}^{-1}\right.$ body mass at warm-up and $0.48 \mathrm{~g} \mathrm{~kg}^{-1}$ body mass at half-time) attenuated the decline in blood glucose concentration at $60 \mathrm{~min}$ in comparison to maltodextrin $(-4 \%$ versus $-19 \%, p=0.015)$. Moreover, both isomaltulose and maltodextrin lowered the rise in plasma epinephrine concentrations in response to prolonged exercise, albeit isomaltulose proved most effective at 90 and $120 \mathrm{~min}$. Thus, the ingestion of isomaltulose beverages $(8-10 \% w / v)$ may serve as an additional nutritional strategy for team sports players (e.g., soccer) when limited inplay feeding opportunities exist during prolonged high-intensity intermittent exercise [52] Interestingly, during a heavy resistance training program, the recovery benefits of whey protein might be enhanced with the addition of $\beta$-Hydroxy- $\beta$-methylbutyrate (HMB) and isomaltulose, which has shown to have significant reductions in markers of muscle damage while improving athletic performance [53]. In addition, Amano et al. (2019) demonstrated that the ingestion of a $6.5 \% \mathrm{w} / v$ isomaltulose drink plus electrolytes $\left(\mathrm{Na}^{+}, \mathrm{Ca}^{2+}, \mathrm{Mg}^{2+}\right.$ and $\mathrm{K}^{+}$) may optimize post-exercise rehydration without affecting heat loss responses in healthy and physically active young men [54]. Therefore, current evidence suggests that low glycemic and low insulinemic properties of non-starch slowly digestible carbohydrates appear of a particular interest in sports nutrition and cognitive performance $[55,56]$. Further research is still needed due to the heterogeneity of the studies, and reports of negligible effects when conditions of the athletes are matched for carbohydrates and energy [18].

\subsubsection{Trehalulose (BCSDB ID: 111199; ChEBI: 79284)}

Chemically called 1-O- $\alpha$-D-glucopyranosyl-D-fructose, trehalulose is a less known non-starch slowly digestible carbohydrate. This disaccharide is also an isomer of sucrose and is found in small amounts in honey but unlike isomaltulose it has no crystallization structure and is therefore found as an amorphous solid [57]. Trehalulose is synthesized by both the trehalulose synthase and as a coproduct by the same isomerase enzyme that synthesizes isomaltulose, but in generally smaller yields (Figure 3). Whereas the production of isomaltulose is kinetically favored, trehalulose is thermodynamically favored, so it tends to accumulate only after long reaction times [58]. Its relative sweetness to sucrose is between 0.4 and 0.7 , which is particularly interesting for physically active diabetic individuals, or sportsmen, because of its similar properties to isomaltulose [59]; however, research is needed in this regard. 


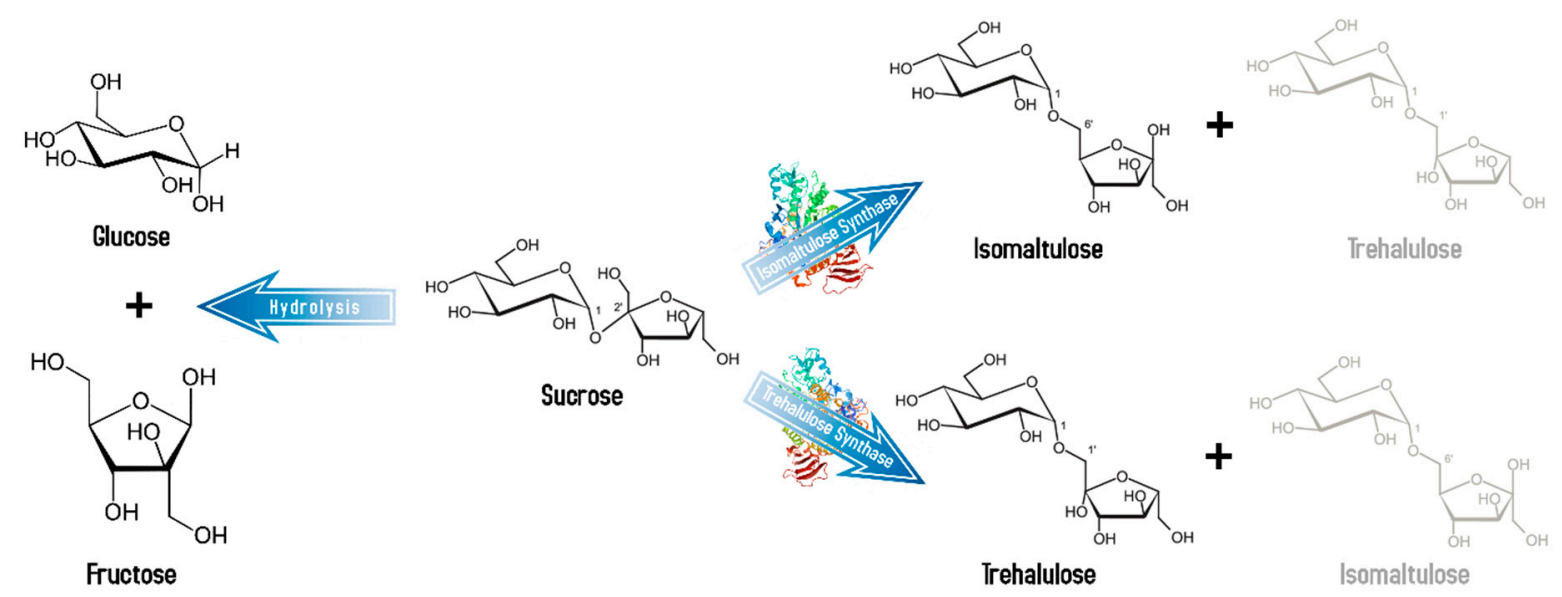

Figure 3. Isomaltulose and trehalulose production. Synthesis of the non-starch slowly digestible sucrose isomers by the isomaltulose synthase (PDB ID: 1M53) and trehalulose synthase (PDB ID: 1ZJA). Minor products of the reaction are represented by faint text. Blood glucose and insulin levels in humans after oral administration of these carbohydrates rise slower and reach lower maxima than after sucrose administration [60]. After hydrolysis of these disaccharides by the human small intestinal mucosal enzymes, fructose and glucose are metabolized as typical for these monosaccharides.

\subsubsection{Modified Starches and High-Molecular Weight Carbohydrates}

Starch is the most common carbohydrate and can be classified as rapidly digestible, slowly digestible and resistant starch, where the speed parameter refers to how easily the enzymes hydrolyze the starch and, therefore, how quickly the blood glucose concentration is affected [61]. Starch modification has been carried out for a long time ago (approximately since the 1800s). Although several advances have been performed in regards to the chemical composition, which results in new nutritional properties, it is important to consider the consumer's health and the environmental impact [62]. Generally, these modifications lead to carbohydrates with a higher number of ramifications, which increases the molecular weight of the compound. The high-molecular weight carbohydrates have the highest values among the available carbohydrates, ranging from $500,000 \mathrm{~g} \cdot \mathrm{mol}^{-1}$ to more than several million $\mathrm{g} \cdot \mathrm{mol}^{-1}$, in comparison to amylose molecules (between 150,000 and $\left.1,000,000 \mathrm{~g} \cdot \mathrm{mol}^{-1}\right)$, the conventional sports drink mixes $\left(\approx 500 \mathrm{~g} \cdot \mathrm{mol}^{-1}\right)$ or the mere sucrose $\left(180 \mathrm{~g} \cdot \mathrm{mol}^{-1}\right)$. This high molecular weight provides a very low osmolarity and therefore accelerates its passage through the stomach to the intestine [63]. Piehl-Aulin et al. [64] found, in well-trained male physical education students, that the osmolality of a carbohydrate drink influenced the rate of muscle glycogen resynthesis after its depletion by exercise when compared the effects of a polyglucoside with a molecular mass between 500,000 and $700,000 \mathrm{~g} \cdot \mathrm{mol}^{-1}\left(84 \mathrm{mOsm} \cdot \mathrm{L}^{-1}\right)$ and a carbohydrate drink with glucose monomers and oligomers with a molecular mass of approximately $500 \mathrm{~g} \cdot \mathrm{mol}^{-1}$ ( $350 \mathrm{mOsm} \cdot \mathrm{L}^{-1}$ ). Hence, the consumption of high-molecular weight carbohydrates was proposed as an effective alternative to favor the post-exercise muscle (and probably hepatic) glycogen resynthesis, which might be of practical importance for athletes wishing to optimize performance during recovery following prolonged sub-maximal exercise [65]. Oliver et al. (2016) showed that this type of carbohydrate improved performance during subsequent repeated maximal explosive resistance training in strength-trained individuals [66]. Nonetheless, more studies are required under standardized conditions to have definitive conclusions according to the athletic population due to certain heterogeneity in the reported results [67-69].

\subsubsection{Cyclodextrins (ChEBI: 495055) and Derivates}

The cyclodextrins are molecules consisting of $\alpha$-D-glucopyranose units linked by $\alpha-(1 \rightarrow 4)$ glycosidic bonds that resemble in shape a basket and are products derived from enzymatic digestion of starch using cyclodextrin glycosyltransferases (CGTases) obtained 
from microorganisms such as Bacillus macerans, Klebsiella oxytoca, Bacillus circulans, and Alkalophylic bacillus [70]. These CGTases act on pre-hydrolyzed starch through several transglycosylations to obtain some helical amylose molecules, which are finally cleaved at regular intervals of six, seven and eight glucose units in the absence of water to generate $\alpha-, \beta$ - and $\gamma$-cyclodextrin, respectively [71]. Although these three are the most abundant naturally occurring forms, besides the major products of CGTases, it has been reported that minor products contain trace amounts of larger cyclic glucans $\left(\delta_{-}, \varepsilon_{-}^{-}, \zeta_{-}, \eta_{-}^{-}\right.$, and $\theta$-cyclodextrins) [72]. Taking into account the stabilized and symmetrical form of cyclodextrins [73], these molecules have been used as drug delivery agents due to their ability to protect molecules from physical, chemical, and biological (enzymatic) degradation [74] and also their ability to solubilize hydrophobic drugs (also known as cyclodextrin complexation) [75].

Cyclodextrins have glycosidic bonds that salivary amylases are able to hydrolyze but they act slowly due to thermodynamic parameters [76]; therefore, cyclodextrins have very low glycemic indexes and provide a longer time of glucose supply to the bloodstream [77,78]. Almost $98 \%$ of these glucose-based rings pass through the small intestine without being absorbed, reaching the large intestine where they are metabolized by the intestinal microbiota to compounds such as acyclic maltodextrin, maltose, glucose, etc., and are finally absorbed [79]. As they are considered tasteless, odorless, non-digestible, non-caloric, and non-cariogenic saccharides, cyclodextrins represent dietary fibers useful in controlling body mass and blood lipid profile besides improving the intestinal microbiota through the selective proliferation of Bifidobacterium. These anti-obesity and anti-diabetic effects make them bioactive nutritional supplements and nutraceuticals [79].

On the other hand, derivatives have been developed with potential application in the sports field such as highly branched cyclic dextrin (HBCD), which is a polymer of +900 glucose residues with a molecular mass between 160,000 and $400,000 \mathrm{~g} \cdot \mathrm{mol}^{-1}$. Due to its relatively high weight and narrow molecular distribution, HBCD has a low osmolarity (a $10 \%$ HBCD solution has an osmotic pressure of $9 \mathrm{mOsm} \cdot \mathrm{kg}^{-1}$ ) that could favor gastric emptying, which is why it can be used to produce a sports drink without increasing the osmotic pressure too much, reaching $150 \mathrm{mOsm} \cdot \mathrm{kg}^{-1}$ when added minerals, vitamins, and organic acids $[80,81]$. HBCD is produced from the processing of waxy corn starch using bacterial-derived $\alpha$-amylase and $\alpha$-(1 $\rightarrow 4)$-glucan-branching enzyme (EC 2.4.1.18), a member of the broader group of glucanotransferases with validated results regarding the safety for human consumption [77]. Several studies have shown not only improvements at the gastrointestinal level [82] and a reduction on the gastric emptying time [78] but also positive effects on endurance sports performance [83], a decrease in the rating of perceived exertion during prolonged exercise [84] and even an attenuation in the stress hormonal response and reduction of urinary cytokine levels after extensive exercise in triathletes [85]. Figure 4 shows the molecular structures of common cyclodextrins and a schematic representation of HBCD.

These emerging modified carbohydrates not only offer metabolic and energy efficiency advantages (by regulating the use of substrates during exercise) but may also benefit certain species of microorganisms in the gut of athletes by acting as a source of non-digestible fiber [90]. In fact, the gut microbiome can rapidly respond to altered diet, potentially facilitating the diversity of human dietary lifestyles; for instance, the low consumption of dietary fiber and resistant starch may lead to a decrease in bowel movements resulting in decreased intestinal function, which would decrease the diversity of intestinal bacteria [91]. Thus, modulation of microbiota by means of probiotic/prebiotic supplementation has shown to ameliorate oxidative stress and inflammation and to improve performance in certain athletic populations but more rigorous studies are needed [92-94]. 
A.

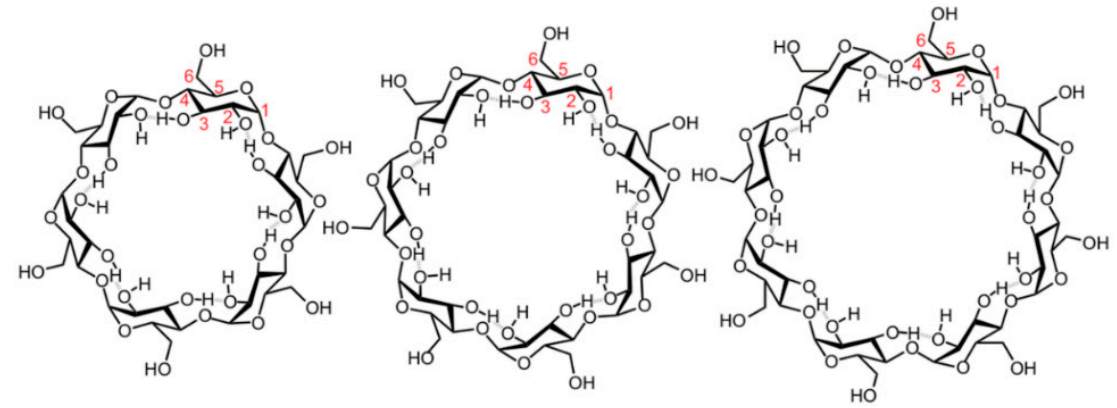

B.
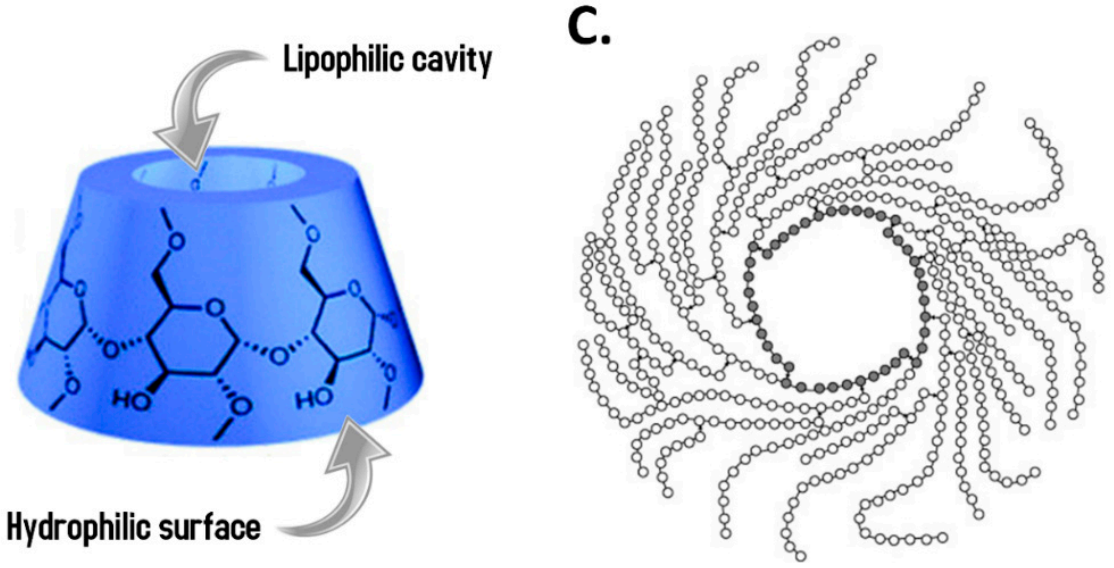

Figure 4. Molecular structures of common cyclodextrins and schematic representation of highly branched cyclic dextrin (HBCD). (A). Chemical structure of the $\alpha-, \beta$ - and $\gamma$-cyclodextrins, which contain 6, 7 or 8 glucose units, respectively. Image taken and modified from [86]. (B). The conical shape representation of cyclodextrins. These molecules have a truncated cone shape with a hydrophilic external surface (due to the hydroxyl groups on the C2, C3 and C6 atoms) and a hydrophobic cavity (due to the inner hydrogens (H3 and $\mathrm{H} 5$ ) pointing inward) [87]. Cyclodextrins have different water solubility: $\alpha$ - and $\gamma$-cyclodextrins have a relatively high solubility (145 and $232 \mathrm{~g} \cdot \mathrm{L}^{-1}$ ), whereas the $\beta$-type is much less soluble in water $\left(18.5 \mathrm{~g} \cdot \mathrm{L}^{-1}\right)$. Image taken and modified from [88]. (C). The schematic representation of HBCD is shown. Open circles represent glucose units while grey-filled circles are those conforming the main centered ring. Lines and arrows are $\alpha-(1 \rightarrow 4)$ and $\alpha-(1 \rightarrow 6)$ glycosidic bonds, respectively. Image taken from [89].

\subsection{Repair}

Scientific research has demonstrated that muscle protein synthesis (MPS) can be stimulated by either a physical allostatic challenge (e.g., resistance exercise stimulus) or by the ingestion of dietary protein, with synergistic responses when protein is consumed before and immediately after resistance exercise training [95]. According to the International Society of Sports Nutrition position stand on nutrient timing, post-exercise ingestion (immediately to $2 \mathrm{~h}$ ) of high-quality protein food represents a robust stimulus that impacts positively on MPS; however, similar increases in MPS have been found when high-quality proteins are ingested immediately before exercise [96]. Indeed, taking into account the sport-specific daily needs, if an insufficient amount of protein is consumed, the athletes will develop and maintain a negative nitrogen balance, which is an indicator of protein catabolism and negatively affect recovery. Over time, this can lead to muscle wasting, injury, disease and intolerance to training [37]. Thus, the peri-exercise ingestion of insulinotropic protein and/or essential amino acid mixtures might stimulate post-exercise net muscle protein anabolism, and this might contribute to faster tissue growth and repair [34]. Similarly, recent findings have provided evidence that marathon runners that consume moderate amounts of protein post-exercise can have recovery benefits $[97,98]$. With a good grade of evidence, compared to ingestion of carbohydrate alone, co-ingestion of carbohydrate plus 
protein together during the recovery period have resulted in no difference in the rate of muscle glycogen synthesis but it improves net protein balance [18].

The International Society of Sports Nutrition position stand [95] about proteins for recovery is:

- Optimal dose of protein for athletes to enhance MPS are dependent upon age, energy intake (higher amount is needed under energy restriction), and recent resistance exercise stimuli. Post-exercise recommendations are $0.5 \mathrm{~g}$ of a high-quality protein per kilogram of body mass, or an absolute dose of $40 \mathrm{~g}$. Protein per meal should be between 0.25 and $0.40 \mathrm{~g}$ of protein per $\mathrm{kg}$ of body mass, or absolute values of $20 \mathrm{~g}$.

- Given the observed benefits of pre- and post-exercise protein ingestion, athletes' tolerance should be assessed to determine the optimal time period during which to ingest protein. Notwithstanding, in spite of the anabolic effect of exercise is longlasting (at least $24 \mathrm{~h}$ ), athletes can take advantage of the higher muscle sensitivity to nutrient uptake after exercise due to the likely diminishment over time.

On the other hand, a large body of evidence suggests that creatine monohydrate supplementation $\left(0.1 \mathrm{~g} \cdot \mathrm{kg}^{-1} \cdot \mathrm{day}^{-1}\right)$ not only optimize exercise adaptations and increase performance but also may reduce muscle damage and/or enhance recovery from intense exercise [99]. These effects are partially due to the optimization of the creatine kinase (CK) system which not only serves as a spatial/temporal buffer of ATP regeneration but also leads to positive regulation of anabolic signaling pathways (such as IGF-I and MAPK) and, hence, might promote faster tissue repair and recovery [100]. Additionally, it has been shown that chronic creatine supplementation prior to an exhaustive exercise bout and glycogen loading promotes greater glycogen resynthesis than just carbohydrate loading alone [101].

The role of antioxidants and anti-inflammatory substances are also highlighted in the post-exercise repair process. An increased antioxidant status leads to the reduction of oxidative stress caused by the production of reactive oxygen species during the inflammatory process [102]; therefore, the use of antioxidants can reduce muscle soreness and help with recovery in the short term, but high doses have also been linked to reduced training benefits in the long term. For example, Levers et al. (2015) found significant beneficial effects on serum markers of muscle catabolism, physiological stress, and inflammatory mechanisms after a short-term supplementation with $480 \mathrm{mg} \cdot \mathrm{day}^{-1}$ of Montmorency powdered tart cherries surrounding a single bout of resistance exercise [103]. More recently, Brown et al. (2019) also reported that supplementation with Montmorency cherry concentrate can be considered as a practical nutritional intervention to reduce symptoms of muscle damage and improve post-exercise recovery on subsequent days in females [104]. It appears that secondary metabolites with antioxidant properties that are found in tart cherry extract might attenuate muscle soreness, strength decrement during recovery, and markers of muscle catabolism in resistance-trained individuals. In this sense, a systematic review and metaanalysis about the effects of antioxidants consumption showed that short-term polyphenol supplementation (e.g., quercetin) may boost athletic performance in predominately-trained males with an average intervention dose of $688 \pm 478 \mathrm{mg} \cdot$ day $^{-1}$ [105]. This has been reinforced by more recent research showing that acute and chronic supplementation with $>1000 \mathrm{mg}$ fruit-derived polyphenols per day will enhance recovery following muscle damage via antioxidant and anti-inflammatory mechanisms [106]; which suggest that fruit supplements could be used as part of the post-exercise recovery strategy although the need to educate and encourage athletes to consume more fruits and vegetables in the diet should be associated not only with recovery but also with health [107]. Similarly, curcumin is rich in polyphenols and has shown anti-inflammatory and antioxidant properties. The supplementation with $6 \mathrm{~g}$ of curcumin and $60 \mathrm{mg}$ of piperine each day between $48 \mathrm{~h}$ before and $48 \mathrm{~h}$ after exercise-induced muscle damage have resulted in positive effects on recovery of the muscle function at $24 \mathrm{~h}$ and $48 \mathrm{~h}$ after the exercise [108].

The use of beetroot juice has been investigated in the management of hypertension $[109,110]$, for the improvement of physical performance $[111,112]$, and also in post- 
exercise recovery [113]. It has been found that acute supplementation of beetroot juice $(250 \mathrm{~mL}) \times 3$ servings, two serving $24 \mathrm{~h}$ and $48 \mathrm{~h}$ following completion of 100-drop jumps attenuated muscle soreness and decrements in countermovement jump performance induced by eccentric exercise, while apparently having no effect on maximal isometric voluntary contractions, CK and some inflammatory markers (IL-6, TNF-alpha and IL-8) [114]. Interestingly, a betalain-rich concentrate of beetroots has shown to improve performance in competitive male and female triathletes and attenuated the increase of CK and fatigue suggesting an increase in recovery [115]. Other herbal and mushroom supplements that have promising effects to improve post-exercise recovery are Zingiber officinale [116], Zingiber officinale + Bixa orellana L. [117], Rhodiola rosea [118], Cordyceps militaris [119], and Rhodiola rosea + Cordyceps sinensis [120]. A root extract that warrants special attention is Withania somnifera (most known as ashwagandha) given some research have found ergogenic effects in athletic [121,122] and physically active individuals [123]. Moreover, the adaptogenic, anti-inflammatory, and antioxidant properties of ashwagandha [124-126] turns this herbal extract into a potential strategy to optimize recovery and promote exercise-induced adaptations. Although more research is required, dosages are between 300 and $500 \mathrm{mg}$ of aqueous root extract twice per day.

On the other hand, it appears that supplementation with branched-chain amino acids (BCAA) after high-intensity exercise may favor a hormonal environment that contributes to attenuate the loss of strength, reduce muscle damage, and generate an anabolic environment [127]. Indeed, several systematic reviews and meta-analysis have concluded that BCAA supplementation $\left(>200 \mathrm{mg} \cdot \mathrm{kg}^{-1} \cdot \mathrm{day}^{-1}\right)$ may optimize recovery and mitigate muscle soreness following muscle-damaging exercise [128-131]. Notwithstanding, in resistance-trained males, the attenuation of muscular performance decrements and the observed decrease in plasma CK levels after BCAA supplementation is likely negligible when consumed with a diet consisting of $\sim 1.2 \mathrm{~g} \cdot \mathrm{kg}^{-1} \cdot \mathrm{day}^{-1}$ of protein [132]. The leucinederived compound HMB has shown to improve work capacity recovery after high-intensity exercise [133], and may attenuate markers of muscle damage, augment acute immune and endocrine responses while preventing loss of lean body mass in catabolic situations [134]. A recent systematic review and meta-analysis by Rahimi et al. (2018) concluded that HMB may be seen as a recovery agent following exercise-induced muscle damage [135], but more research on recovery from injury that includes periods of extreme inactivity is needed given it does not consistently increase strength and/or lean mass or reduce markers of muscle damage [136]. Finally, it has been recently reviewed systematically if other foods, such as Pomegranate [137], cow's milk [138], or Chocolate milk [139], might potentially improve exercise-performance and post-exercise recovery but further research is needed to extract definitive conclusions.

\subsection{Rest}

There is no doubt that sleep is an absolutely vital physiological function and one of the most important factors in post-exercise recovery [140]. It has been emphasized that naps, sleep extension, and sleep-hygiene practices seem to be advantageous to the performance by optimizing recovery [141]. In spite of the above, von Rosen et al. (2017) reported that the recommended amount of sleep during weekdays $(8 \mathrm{~h})$ was not obtained by $19 \%$ of 340 Swedish adolescent elite athletes of several disciplines during the autumn semester. Moreover, athletes sleeping more than eight hours and reached the recommended nutrition intake reduced the odds of suffering a new injury [142]. Portuguese elite female gymnasts have also found to have poor sleep habits with consequences on daytime sleepiness, sleep quality, and low energy availability associated with macro and micronutrients ${ }^{\prime}$ deficiencies [143]. In fact, according to a recent systematic review by Gupta et al. [144], athletes show a high overall prevalence of insomnia symptoms characterized by increased sleep latency, sleep fragmentation, non-restorative sleep, and excessive daytime fatigue. Currently, there is a lack of evidence and future research should focus on conducting sleep 
interventions among different athlete populations to address their specific sleep demands and disturbances [145].

It is known that eating the right combination of foods before going to sleep and what foods to avoid in the evening may be beneficial in enhancing sleep [146]. That is the rationale for the pre-sleep nutrition strategies, considering that several nutrients have been shown to improve sleep such as carbohydrates (high-glycemic index dinners), melatonin, tryptophan-rich protein, antioxidant-rich fruits (e.g., tart cherry juice and kiwi), and micronutrients [147]. Casein proteins, a type of secreted calcium (phosphate)-binding phosphoproteins, are among the most common nutrients used for pre-sleep nutrition given they are considered a high-quality protein source with high digestibility and bioavailability but with a slower digestion rate in comparison to whey [148]. Thus, the timing of nutrient intake is as important as the composition to fulfill the nutrition needs of the athletes [96]. Res et al. [149] reported for the first time that casein protein ingestion immediately before sleep was not only effectively digested and absorbed but also increased MPS and net protein balance in healthy young males that performed a resistance-training bout in the evening. Moreover, it has been demonstrated that pre-sleep casein protein ingestion augments the muscle adaptive response in terms of muscle mass and strength after a 12-week resistance exercise training program in young men in comparison to placebo [150]. Therefore, the extended window of opportunity as a result of the additive effects of resistance exercise training and protein ingestion on MPS makes the pre-sleep casein protein supplementation an effective nutrient timing strategy to optimize muscle conditioning and recovery [151] with no need to add extra leucine [152]. Although the positive effects of pre-sleep nutrition have been found particularly in resistance-type exercise training [153], more research is needed in endurance-trained athletes considering recent findings showed no improvement [154]. The available evidence and recommendations under this new paradigm of pre-sleep nutrition are:

- The consumption of 40-48 $\mathrm{g}$ of casein approximately $30 \mathrm{~min}$ before sleep improves post-exercise recovery and positively affect acute protein metabolism during an overnight period in healthy young adults $[148,155]$.

- Ashwagandha supplementation (>150 mg aqueous root extract quaque hora somni) seems to be an effective nutritional strategy to improve sleep quality in healthy male and female subjects [156]; consequently, it should be also considered before sleep.

\section{Conclusions}

Several nutritional strategies may be used to optimize post-exercise recovery. The amount, composition, and timing for the consumption of fluids, electrolytes, macronutrients, antioxidants and/or supplements depend on the type of sport, the time between sessions, the level of preparation of the athlete, the convenience of the strategy, among other factors. There is not a single protocol to apply in post-exercise recovery. Based on the available evidence, we have identified a mnemonic entitled the $4 R^{\prime} \mathrm{s}$ which stands for Rehydrate, Refuel, Repair, and Rest. These four R's are not intending to replace the current methodologies or to establish a novel rigid paradigm in this regard, but to represent a strategic application of the nutritional strategies that should be taken into account during the recovery process. Taking into account the allostasis model, it is important to consider that each $R$ represents a factor with tremendous influence on the allostatic response and the allostatic load that will impact the exercise-induced adaptions and recovery.

Rehydrate-It is necessary to guarantee the post-exercise consumption of at least $150 \%$ of the weight lost during the event $\left(\sim 1.5 \mathrm{~L} \cdot \mathrm{kg}^{-1}\right)$ accompanied by sodium (if a faster replacement is required).

Refuel-The combined use of carbohydrates and proteins is a good strategy to replenish glycogen while contributing to tissue repair. Although new bioengineered formulations have been developed and introduced to the market, the source of macronutrients for men and women may be diverse and need not be limited to exclusively commercial sport nutrition products as long as an adequate amount of carbohydrates is provided at multiple 
intervals during post-exercise recovery [157]. Special attention should be paid to non-starch slowly digestible carbohydrates that have not been widely studied, such as trehalulose.

Repair-The ingestion of high-quality protein stimulates post-exercise net muscle protein anabolism and might contribute to faster tissue growth and repair. The use of certain supplements such as creatine monohydrate, tart cherry, beetroot juice, and possible ashwagandha might help to enhance recovery.

Rest-Optimal sleeping time and quality are necessary to benefit the allostatic response after exercise. Pre-sleep casein protein ingestion seems to be an effective strategy to boost the muscle adaptive response during a resistance exercise training program but more research is needed in endurance athletes.

Author Contributions: Conceptualization, A.P.-I. and D.A.B.; writing-original draft preparation, A.P.-I. and D.A.B.; writing-critical review, A.O.-M. and R.B.K.; writing-final preparation for submission, D.A.B. All authors have read and agreed to the published version of the manuscript.

Funding: The APC was funded by the Exercise \& Sport Nutrition Laboratory (Texas A\&M).

Institutional Review Board Statement: Not applicable.

Informed Consent Statement: Not applicable.

Acknowledgments: The authors would like to thank all DBSS International fellows, invited speakers and attendants to the Ibero-American Symposium in Sports and Physical Activity: Nutrition and Training-SIDANE, which has been held in Colombia, México, Costa Rica and Perú, and where this topic has been fully covered.

Conflicts of Interest: D.A.B. serves as a Science Product Manager for a company of dietary supplements in Europe (MTX Corporation ${ }^{\circledR}$ ), has acted as scientific consultant for MET-Rx in Colombia, and is current member of the "Creatine in Health" scientific advisory board for Creapure ${ }^{\circledR}$-AlzChem Tostberg GmbH. R.B.K. has conducted a number of industry sponsored on sport nutrition related nutrients, has served as a paid consultant and received honorariums to speak at conferences by industry, and currently serves as chair of the "Creatine in Health" scientific advisory board for Creapure ${ }^{\circledR}$ AlzChem Tostberg GmbH. A.P.-I. and A.O.-M. declare no conflict of interest. This review does not constitute endorsement by the authors and/or the institution concerning the nutrients reviewed.

\section{References}

1. Leveille, C.F.; Mikhaeil, J.S.; Turner, K.D.; Silvera, S.; Wilkinson, J.; Fajardo, V.A. Mitochondrial cristae density: A dynamic entity that is critical for energy production and metabolic power in skeletal muscle. J. Physiol. 2017, 595, 2779-2780. [CrossRef] [PubMed]

2. Nielsen, J.; Gejl, K.D.; Hey-Mogensen, M.; Holmberg, H.-C.; Suetta, C.; Krustrup, P.; Elemans, C.P.H.; Ørtenblad, N. Plasticity in mitochondrial cristae density allows metabolic capacity modulation in human skeletal muscle. J. Physiol. 2017, 595, $2839-2847$. [CrossRef] [PubMed]

3. Hughes, D.C.; Ellefsen, S.; Baar, K. Adaptations to Endurance and Strength Training. Cold Spring Harb. Perspect. Med. 2018, 8. [CrossRef] [PubMed]

4. Lambert, M.I. Training, Adaptations. In Encyclopedia of Exercise Medicine in Health and Disease; Mooren, F.C., Ed.; Springer: Berlin/Heidelberg, Germany, 2012; pp. 854-856.

5. Sundberg, C.W.; Fitts, R.H. Bioenergetic basis of skeletal muscle fatigue. Curr. Opin. Physiol. 2019, 10, 118-127. [CrossRef]

6. Hunter, S.K. Performance Fatigability: Mechanisms and Task Specificity. Cold Spring Harb. Perspect. Med. 2018, 8. [CrossRef]

7. Sundberg, C.W.; Hunter, S.K.; Trappe, S.W.; Smith, C.S.; Fitts, R.H. Effects of elevated $\mathrm{H}^{+}$and $\mathrm{P}_{\mathrm{i}}$ on the contractile mechanics of skeletal muscle fibres from young and old men: Implications for muscle fatigue in humans. J. Physiol. 2018, 596, $3993-4015$. [CrossRef]

8. Sterling, P. Allostasis: A model of predictive regulation. Physiol. Behav. 2012, 106, 5-15. [CrossRef]

9. Burke, L. Nutricion en el Deporte/Nutrition in Sport: Un Enfoque Práctico/a Practical Approach; Editorial Médica Panamericana S.A.: Madrid, Spain, 2010.

10. Zoorob, R.; Parrish, M.-E.E.; O’Hara, H.; Kalliny, M. Sports Nutrition Needs. Prim. Care 2013, 40, 475-486. [CrossRef]

11. Ivy, J.L.; Ferguson-Stegall, L.M. Nutrient Timing. Am. J. Lifestyle Med. 2013, 8, 246-259. [CrossRef]

12. Edes, A.N.; Crews, D.E. Allostatic load and biological anthropology. Am. J. Phys. Anthropol. 2017, 162, 44-70. [CrossRef]

13. Egan, B.; Zierath, J.R. Exercise Metabolism and the Molecular Regulation of Skeletal Muscle Adaptation. Cell Metab. 2013, 17, 162-184. [CrossRef] [PubMed] 
14. Robinson, M.M.; Dasari, S.; Konopka, A.R.; Johnson, M.L.; Manjunatha, S.; Esponda, R.R.; Carter, R.E.; Lanza, I.R.; Nair, K.S. Enhanced Protein Translation Underlies Improved Metabolic and Physical Adaptations to Different Exercise Training Modes in Young and Old Humans. Cell Metab. 2017, 25, 581-592. [CrossRef] [PubMed]

15. Karagounis, L.G.; Hawley, J.A. Genes, Exercise, and Glucose and Insulin Metabolism. In Genetic and Molecular Aspects of Sport Performance; John Wiley \& Sons Ltd.: Chichester, UK, 2010; pp. 240-248. [CrossRef]

16. Hood, D.A. Invited Review: Contractile activity-induced mitochondrial biogenesis in skeletal muscle. J. Appl. Physiol. 2001, 90, 1137-1157. [CrossRef] [PubMed]

17. Jeukendrup, A.E. Periodized Nutrition for Athletes. Sports Med. 2017, 47, 51-63. [CrossRef] [PubMed]

18. Thomas, D.T.; Erdman, K.A.; Burke, L.M. Position of the Academy of Nutrition and Dietetics, Dietitians of Canada, and the American College of Sports Medicine: Nutrition and Athletic Performance. J. Acad. Nutr. Diet. 2016, 116, 501-528. [CrossRef]

19. Kreider, R.B. Essentials of Exercise E Sport Nutrition: Science to Practice; Lulu Press, Inc.: Morrisville, CA, USA, 2019.

20. American College of Sports Medicine; Sawka, M.N.; Burke, L.M.; Eichner, E.R.; Maughan, R.J.; Montain, S.J.; Stachenfeld, N.S. Exercise and Fluid Replacement. Med. Sci. Sports Exerc. 2007, 39, 377-390. [CrossRef] [PubMed]

21. Kreider, R.B. Physiological Considerations of Ultraendurance Performance. Int. J. Sport Nutr. 1991, 1, 3-27. [CrossRef]

22. McCubbin, A.J.; Allanson, B.A.; Caldwell Odgers, J.N.; Cort, M.M.; Costa, R.J.S.; Cox, G.R.; Crawshay, S.T.; Desbrow, B.; Freney, E.G.; Gaskell, S.K.; et al. Sports Dietitians Australia Position Statement: Nutrition for Exercise in Hot Environments. Int. J. Sport Nutr. Exerc. Metab. 2020, 30, 83-98. [CrossRef]

23. Roberts, W.O.; O'Connor, F.G.; Kenney, W.L.; Cooper, L.; Cheuvront, S.N.; Casa, D.J.; Armstrong, L.E.; Anderson, S.A.; McDermott, B.P. National Athletic Trainers' Association Position Statement: Fluid Replacement for the Physically Active. J. Athl. Train. 2017, 52, 877-895. [CrossRef]

24. Merson, S.J.; Maughan, R.J.; Shirreffs, S.M. Rehydration with drinks differing in sodium concentration and recovery from moderate exercise-induced hypohydration in man. Eur. J. Appl. Physiol. 2008, 103, 585-594. [CrossRef]

25. Kavouras, S.A.; Armstrong, L.E.; Maresh, C.M.; Casa, D.J.; Herrera-Soto, J.A.; Scheett, T.P.; Stoppani, J.; Mack, G.W.; Kraemer, W. Rehydration with glycerol: endocrine, cardiovascular, and thermoregulatory responses during exercise in the heat. J. Appl. Physiol. 2005, 100, 442-450. [CrossRef] [PubMed]

26. Van Rosendal, S.P.; Coombes, J.S. Glycerol Use in Hyperhydration and Rehydration: Scientific Update. In Acute Topics in Sport Nutrition; Karger AG: Basel, Switzerland, 2012; pp. 104-112. [CrossRef]

27. Perez-Idarraga, A.; Aragon-Vargas, L.F. Postexercise rehydration: Potassium-rich drinks versus water and a sports drink. Appl. Physiol. Nutr. Metab. = Physiol. Appl. Nutr. Metab. 2014, 39, 1167-1174. [CrossRef] [PubMed]

28. Aragón-Vargas, L.F.; Pérez Idárraga, A. Rehidratación posejercicio: La forma de distribuir la ingesta de un volumen constante de líquido no altera su conservación. Pensar En Mov. Rev. Cienc. Ejerc. Salud 2011, 9, 12-21. [CrossRef]

29. Aragón-Vargas, L.F.; Pérez-Idárraga, A. Post-Exercise Rehydration: No Change in Diuresis from Water Ingested at Different Temperatures. Med. Sport. 2010, 14, 77-82. [CrossRef]

30. Sandick, B.L.; Engell, D.B.; Maller, O. Perception of drinking water temperature and effects for humans after exercise. Physiol. Behav. 1984, 32, 851-855. [CrossRef]

31. Karp, J.R.; Johnston, J.D.; Tecklenburg, S.; Mickleborough, T.D.; Fly, A.D.; Stager, J.M. Chocolate milk as a post-exercise recovery aid. Int. J. Sport Nutr. Exerc. Metab. 2006, 16, 78-91. [CrossRef]

32. Roy, B.D. Milk: The new sports drink? A Review. J. Int. Soc. Sports Nutr. 2008, 5, 15. [CrossRef]

33. Shirreffs, S.M.; Watson, P.; Maughan, R.J. Milk as an effective post-exercise rehydration drink. Br. J. Nutr. 2007, 98, 173-180. [CrossRef]

34. Jentjens, R.; Jeukendrup, A. Determinants of post-exercise glycogen synthesis during short-term recovery. Sports Med. 2003, 33, 117-144. [CrossRef]

35. Burke, L.M.; Loucks, A.B.; Broad, N. Energy and carbohydrate for training and recovery. J. Sports Sci. 2006, 24, 675-685. [CrossRef]

36. Mujika, I.; Burke, L.M. Nutrition in Team Sports. Ann. Nutr. Metab. 2010, 57, 26-35. [CrossRef] [PubMed]

37. Kerksick, C.M.; Wilborn, C.D.; Roberts, M.D.; Smith-Ryan, A.; Kleiner, S.M.; Jäger, R.; Collins, R.; Cooke, M.; Davis, J.N.; Galvan, E.; et al. ISSN exercise \& sports nutrition review update: Research \& recommendations. J. Int. Soc. Sports Nutr. 2018, 15. [CrossRef]

38. Burke, L.M.; Hawley, J.A.; Wong, S.H.; Jeukendrup, A.E. Carbohydrates for training and competition. J. Sports Sci. 2011, 29, S17-S27. [CrossRef] [PubMed]

39. Gonzalez, J.; Fuchs, C.; Betts, J.; van Loon, L. Glucose Plus Fructose Ingestion for Post-Exercise Recovery-Greater than the Sum of Its Parts? Nutrients 2017, 9, 344. [CrossRef] [PubMed]

40. Murray, B.; Rosenbloom, C. Fundamentals of glycogen metabolism for coaches and athletes. Nutr. Rev. 2018, 76, 243-259. [CrossRef]

41. Varðardóttir, B.; Guðmundsdóttir, S.L.; Ólafsdóttir, A.S. Pegar orkuna skortir-áhrif hlutfallslegs orkuskorts í ípróttum (RED-s) á heilsu og árangur. Læknablaðið 2020, 106, 406-413. [CrossRef]

42. Mountjoy, M.; Sundgot-Borgen, J.; Burke, L.; Ackerman, K.E.; Blauwet, C.; Constantini, N.; Lebrun, C.; Lundy, B.; Melin, A.; Meyer, N.; et al. International Olympic Committee (IOC) Consensus Statement on Relative Energy Deficiency in Sport (RED-S): 2018 Update. Int. J. Sport Nutr. Exerc. Metab. 2018, 28, 316-331. [CrossRef] 
43. Toukach, P.V.; Egorova, K.S. Carbohydrate structure database merged from bacterial, archaeal, plant and fungal parts. Nucleic Acids Res. 2016, 44, D1229-D1236. [CrossRef]

44. Degtyarenko, K.; de Matos, P.; Ennis, M.; Hastings, J.; Zbinden, M.; McNaught, A.; Alcantara, R.; Darsow, M.; Guedj, M.; Ashburner, M. ChEBI: A database and ontology for chemical entities of biological interest. Nucleic Acids Res. 2007, 36, D344-D350. [CrossRef]

45. Goulter, K.C.; Hashimi, S.M.; Birch, R.G. Microbial sucrose isomerases: Producing organisms, genes and enzymes. Enzym. Microb. Technol. 2012, 50, 57-64. [CrossRef]

46. Zhang, G.; Ao, Z.; Hamaker, B.R. Controlling the delivery of glucose in foods. In Designing Functional Foods; Woodhead Publishing: Cambridge, UK, 2009; pp. 547-571.

47. König, D.; Theis, S.; Kozianowski, G.; Berg, A. Postprandial substrate use in overweight subjects with the metabolic syndrome after isomaltulose (Palatinose ${ }^{\mathrm{TM}}$ ) ingestion. Nutrition 2012, 28, 651-656. [CrossRef] [PubMed]

48. Kemp, S.; Schweppes, C.; Lindley, M. Developments in sweeteners. In Modifying Flavour in Food; Woodhead Publishing: Cambridge, UK, 2007; pp. 185-201.

49. Bracken, R.M.; Page, R.; Gray, B.; Kilduff, L.P.; West, D.J.; Stephens, J.W.; Bain, S.C. Isomaltulose Improves Glycemia and Maintains Run Performance in Type 1 Diabetes. Med. Sci. Sports Exerc. 2012, 44, 800-808. [CrossRef] [PubMed]

50. König, D.; Zdzieblik, D.; Holz, A.; Theis, S.; Gollhofer, A. Substrate Utilization and Cycling Performance Following Palatinose ${ }^{\mathrm{TM}}$ Ingestion: A Randomized, Double-Blind, Controlled Trial. Nutrients 2016, 8, 390. [CrossRef]

51. Hattori, S.; Noguchi, A.; Sasagawa, K.; Ogata, H.; Kobayashi, M.; Omi, N. Influence of Isomaltulose Ingestion on Fat Oxidation During Inclemental Exercise in Endurance Athletes. Am. J. Sports Sci. 2019, 7. [CrossRef]

52. Stevenson, E.J.; Watson, A.; Theis, S.; Holz, A.; Harper, L.D.; Russell, M. A comparison of isomaltulose versus maltodextrin ingestion during soccer-specific exercise. Eur. J. Appl. Physiol. 2017, 117, 2321-2333. [CrossRef] [PubMed]

53. Kraemer, W.J.; Hooper, D.R.; Szivak, T.K.; Kupchak, B.R.; Dunn-Lewis, C.; Comstock, B.A.; Flanagan, S.D.; Looney, D.P.; Sterczala A.J.; DuPont, W.H.; et al. The Addition of Beta-hydroxy-beta-methylbutyrate and Isomaltulose to Whey Protein Improves Recovery from Highly Demanding Resistance Exercise. J. Am. Coll. Nutr. 2015, 34, 91-99. [CrossRef] [PubMed]

54. Amano, T.; Sugiyama, Y.; Okumura, J.; Fujii, N.; Kenny, G.P.; Nishiyasu, T.; Inoue, Y.; Kondo, N.; Sasagawa, K.; Enoki, Y.; et al Effects of isomaltulose ingestion on postexercise hydration state and heat loss responses in young men. Exp. Physiol. 2019, 104, 1494-1504. [CrossRef]

55. Maresch, C.C.; Petry, S.F.; Theis, S.; Bosy-Westphal, A.; Linn, T. Low Glycemic Index Prototype Isomaltulose-Update of Clinical Trials. Nutrients 2017, 9, 381. [CrossRef]

56. Ferrugem, L.; Martini, G.; de Souza, C. Influence of the Glycemic Index of Pre-exercise Meals in Sports Performance: A Systematic Review. Int. J. Med. Rev. 2018, 5, 151-158. [CrossRef]

57. Surana, R.; Pyne, A.; Suryanarayanan, R. Effect of Preparation Method on Physical Properties of Amorphous Trehalose. Pharm. Res. 2004, 21, 1167-1176. [CrossRef]

58. Côté, G.L. Flavorings and other value-added products from sucrose **Mention of trade names or commercial products is solely for the purpose of providing specific information and does not imply recommendation or endorsement by the US Department of Agriculture. In Novel Enzyme Technology for Food Applications; Woodhead Publishing: Cambridge, UK, 2007; pp. $243-269$.

59. Arai, S.; Morinaga, Y.; Yoshikawa, T.; Ichiishi, E.; Kiso, Y.; Yamazaki, M.; Morotomi, M.; Shimizu, M.; Kuwata, T.; Kaminogawa, S. Recent Trends in Functional Food Science and the Industry in Japan. Biosci. Biotechnol. Biochem. 2014, 66, 2017-2029. [CrossRef] [PubMed]

60. Lina, B.A.R.; Jonker, D.; Kozianowski, G. Isomaltulose (Palatinose $\left.{ }^{\circledR}\right)$ : A review of biological and toxicological studies. Food Chem. Toxicol. 2002, 40, 1375-1381. [CrossRef]

61. Ngo, C. In Vitro Starch Digestion for Analysis of Healthy Carbohydrates. Master's Thesis, Luleå University of Technology, Luleå, Sweden, 2018.

62. Zia ud, D.; Xiong, H.; Fei, P. Physical and chemical modification of starches: A review. Crit. Rev. Food Sci. Nutr. 2017, 57, 2691-2705. [CrossRef] [PubMed]

63. Pfeiffer, A.; Schmidt, T.; Kaess, H. The role of osmolality in the absorption of a nutrient solution. Aliment. Pharmacol. Ther. 1998, 12, 281-286. [CrossRef]

64. Piehl Aulin, K.; Söderlund, K.; Hultman, E. Muscle glycogen resynthesis rate in humans after supplementation of drinks containing carbohydrates with low and high molecular masses. Eur. J. Appl. Physiol. 2000, 81, 346-351. [CrossRef] [PubMed]

65. Stephens, F.B.; Roig, M.; Armstrong, G.; Greenhaff, P.L. Post-exercise ingestion of a unique, high molecular weight glucose polymer solution improves performance during a subsequent bout of cycling exercise. J. Sports Sci. 2008, 26, 149-154. [CrossRef]

66. Oliver, J.M.; Almada, A.L.; Van Eck, L.E.; Shah, M.; Mitchell, J.B.; Jones, M.T.; Jagim, A.R.; Rowlands, D.S. Ingestion of High Molecular Weight Carbohydrate Enhances Subsequent Repeated Maximal Power: A Randomized Controlled Trial. PLoS ONE 2016, 11. [CrossRef]

67. McGlory, C.; Morton, J.P. The Effects of Postexercise Consumption of High-Molecular-Weight versus Low-Molecular-Weight Carbohydrate Solutions on Subsequent High-Intensity Interval-Running Capacity. Int. J. Sport Nutr. Exerc. Metab. 2010, 20,361-369. [CrossRef] 
68. Anzalone, A.J.; Almada, A.L.; Van Eck, L.E.; Jones, M.T.; Jagim, A.R.; Mitchell, J.B.; Shah, M.; Oliver, J.M. Effect of post-exercise ingestion of different molecular weight carbohydrate solutions. Part II: The incretin response. J. Int. Soc. Sports Nutr. $2015,12$. [CrossRef]

69. Mock, M.G.; Hirsch, K.R.; Blue, M.N.M.; Trexler, E.T.; Roelofs, E.J.; Smith-Ryan, A.E. Post-Exercise Ingestion of Low or High Molecular Weight Glucose Polymer Solution Does Not Improve Cycle Performance in Female Athletes. J. Strength Cond. Res. 2018. [CrossRef]

70. Leemhuis, H.; Kelly, R.M.; Dijkhuizen, L. Engineering of cyclodextrin glucanotransferases and the impact for biotechnological applications. Appl. Microbiol. Biotechnol. 2009, 85, 823-835. [CrossRef] [PubMed]

71. Stick, R.V.; Williams, S.J. Disaccharides, Oligosaccharides and Polysaccharides. In Carbohydrates: The Essential Molecules of Life; Elsevier Science: Amsterdam, The Netherlands, 2009; pp. 321-341. [CrossRef]

72. French, D.; Pulley, A.O.; Effenberger, J.A.; Rougvie, M.A.; Abdullah, M. Studies on the Schardinger dextrins. XII. The molecular size and structure of the delta-, epsilon-, zeta-, and eta-dextrins. Arch. Biochem. Biophys. 1965, 111, 153-160. [CrossRef]

73. Avakyan, V.G.; Nazarov, V.B.; Alfimov, M.V.; Bagatur"yants, A.A.; Voronezheva, N.I. The role of intra- and intermolecular hydrogen bonds in the formation of $\beta$-cyclodextrin head-to-head and head-to-tail dimers. The results of ab initio and semiempirical quantum-chemical calculations. Russ. Chem. Bull. 2001, 50, 206-216. [CrossRef]

74. Narayanaswamy, R.; Kanagesan, S.; Pandurangan, A.; Padmanabhan, P. Basics to different imaging techniques, different nanobiomaterials for image enhancement. In Nanobiomaterials in Medical Imaging; William Andrew: Norwich, NY, USA, 2016; pp. 101-129.

75. Semalty, A. Cyclodextrin and phospholipid complexation in solubility and dissolution enhancement: A critical and meta-analysis. Expert Opin. Drug Deliv. 2014, 11, 1255-1272. [CrossRef]

76. Dura, A.; Yokoyama, W.; Rosell, C.M. Glycemic Response to Corn Starch Modified with Cyclodextrin Glycosyltransferase and its Relationship to Physical Properties. Plant Foods Hum. Nutr. 2016, 71, 252-258. [CrossRef]

77. Choi, S.S.H.; Danielewska-Nikiel, B.; Ohdan, K.; Kojima, I.; Takata, H.; Kuriki, T. Safety evaluation of highly-branched cyclic dextrin and a 1,4- $\alpha$-glucan branching enzyme from Bacillus stearothermophilus. Regul. Toxicol. Pharmacol. 2009, 55, 281-290. [CrossRef]

78. Takii, H.; Takii, Y.; Kometani, T.; Nishimura, T.; Nakae, T.; Kuriki, T.; Fushiki, T. Fluids Containing a Highly Branched Cyclic Dextrin Influence the Gastric Emptying Rate. Int. J. Sports Med. 2005, 26, 314-319. [CrossRef]

79. Fenyvesi, É.; Vikmon, M.; Szente, L. Cyclodextrins in Food Technology and Human Nutrition: Benefits and Limitations. Crit. Rev. Food Sci. Nutr. 2015, 56, 1981-2004. [CrossRef]

80. Takata, H.; Kojima, I.; Taji, N.; Suzuki, Y.; Yamamoto, M. Industrial production of branching enzyme, and its application to production of highly branched cyclic dextrin (Cluster Dextrin ${ }^{\mathrm{TM}}$ ). Seibutsu Kogaku Kaishi 2006, 84, 61-66.

81. Kometani, T. Production of novel bioactive compounds by enzymes, and their application to food. Pure Appl. Chem. 2010, 82, 269-287. [CrossRef]

82. Takii, H.; Kometani, T.; Nishimura, T.; Kuriki, T.; Fushiki, T. A Sports Drink Based on Highly Branched Cyclic Dextrin Generates Few Gastrointestinal Disorders in Untrained Men during Bicycle Exercise. Food Sci. Technol. Res. 2004, 10, 428-431. [CrossRef]

83. Shiraki, T.; Kometani, T.; Yoshitani, K.; Takata, H.; Nomura, T. Evaluation of Exercise Performance with the Intake of Highly Branched Cyclic Dextrin in Athletes. Food Sci. Technol. Res. 2015, 21, 499-502. [CrossRef]

84. Furuyashiki, T.; Tanimoto, H.; Yokoyama, Y.; Kitaura, Y.; Kuriki, T.; Shimomura, Y. Effects of ingesting highly branched cyclic dextrin during endurance exercise on rating of perceived exertion and blood components associated with energy metabolism. Biosci. Biotechnol. Biochem. 2014, 78, 2117-2119. [CrossRef] [PubMed]

85. Suzuki, K.; Shiraishi, K.; Yoshitani, K.; Sugama, K.; Kometani, T. Effect of a sports drink based on highly-branched cyclic dextrin on cytokine responses to exhaustive endurance exercise. J. Sports Med. Phys. Fit. 2014, 54, 622-630.

86. Bruns, C.J. Exploring and Exploiting the Symmetry-Breaking Effect of Cyclodextrins in Mechanomolecules. Symmetry 2019, 11, 1249. [CrossRef]

87. Rousseau, J.; Menuel, S.; Rousseau, C.; Hapiot, F.; Monflier, E. Cyclodextrins as Porous Material for Catalysis. In Organic Nanoreactors; Academic Press: London, UK, 2016; pp. 15-42.

88. Baykal, A.; Bozkurt, A.; Jeremy, R.; Asiri, S.M.M.; Lima-Tenório, M.K.; Kaewsaneha, C.; Elaissari, A. Multistimuli-responsive magnetic assemblies. In Stimuli Responsive Polymeric Nanocarriers for Drug Delivery Applications; Woodhead Publishing: Cambridge, UK, 2019; pp. 155-193.

89. Kadota, K.; Senda, A.; Ito, T.; Tozuka, Y. Feasibility of highly branched cyclic dextrin as an excipient matrix in dry powder inhalers. Eur. J. Pharm. Sci. 2015, 79, 79-86. [CrossRef]

90. Fujii, K.; Takata, H.; Yanase, M.; Terada, Y.; Ohdan, K.; Takaha, T.; Okada, S.; Kuriki, T. Bioengineering and Application of Novel Glucose Polymers. Biocatal. Biotransform. 2010, 21, 167-172. [CrossRef]

91. David, L.A.; Maurice, C.F.; Carmody, R.N.; Gootenberg, D.B.; Button, J.E.; Wolfe, B.E.; Ling, A.V.; Devlin, A.S.; Varma, Y.; Fischbach, M.A.; et al. Diet rapidly and reproducibly alters the human gut microbiome. Nature 2013, 505, 559-563. [CrossRef]

92. Huang, W.-C.; Pan, C.-H.; Wei, C.-C.; Huang, H.-Y. Lactobacillus plantarum PS128 Improves Physiological Adaptation and Performance in Triathletes through Gut Microbiota Modulation. Nutrients 2020, 12, 2315. [CrossRef]

93. Jäger, R.; Mohr, A.E.; Carpenter, K.C.; Kerksick, C.M.; Purpura, M.; Moussa, A.; Townsend, J.R.; Lamprecht, M.; West, N.P.; Black, K.; et al. International Society of Sports Nutrition Position Stand: Probiotics. J. Int. Soc. Sports Nutr. 2019, 16. [CrossRef] 
94. Mohr, A.E.; Jäger, R.; Carpenter, K.C.; Kerksick, C.M.; Purpura, M.; Townsend, J.R.; West, N.P.; Black, K.; Gleeson, M.; Pyne, D.B.; et al. The athletic gut microbiota. J. Int. Soc. Sports Nutr. 2020, 17. [CrossRef] [PubMed]

95. Jager, R.; Kerksick, C.M.; Campbell, B.I.; Cribb, P.J.; Wells, S.D.; Skwiat, T.M.; Purpura, M.; Ziegenfuss, T.N.; Ferrando, A.A.; Arent, S.M.; et al. International Society of Sports Nutrition Position Stand: Protein and exercise. J. Int. Soc. Sports Nutr. 2017, 14, 20. [CrossRef] [PubMed]

96. Kerksick, C.M.; Arent, S.; Schoenfeld, B.J.; Stout, J.R.; Campbell, B.; Wilborn, C.D.; Taylor, L.; Kalman, D.; Smith-Ryan, A.E.; Kreider, R.B.; et al. International society of sports nutrition position stand: Nutrient timing. J. Int. Soc. Sports Nutr. 2017, 14. [CrossRef] [PubMed]

97. Saunders, M.J.; Luden, N.D.; DeWitt, C.R.; Gross, M.C.; Dillon Rios, A. Protein Supplementation During or Following a Marathon Run Influences Post-Exercise Recovery. Nutrients 2018, 10, 333. [CrossRef] [PubMed]

98. Churchward-Venne, T.A.; Pinckaers, P.J.M.; Smeets, J.S.J.; Betz, M.W.; Senden, J.M.; Goessens, J.P.B.; Gijsen, A.P.; Rollo, I.; Verdijk, L.B.; van Loon, L.J.C. Dose-response effects of dietary protein on muscle protein synthesis during recovery from endurance exercise in young men: A double-blind randomized trial. Am. J. Clin. Nutr. 2020, 112, 303-317. [CrossRef]

99. Kreider, R.B.; Kalman, D.S.; Antonio, J.; Ziegenfuss, T.N.; Wildman, R.; Collins, R.; Candow, D.G.; Kleiner, S.M.; Almada, A.L.; Lopez, H.L. International Society of Sports Nutrition position stand: Safety and efficacy of creatine supplementation in exercise, sport, and medicine. J. Int. Soc. Sports Nutr. 2017, 14. [CrossRef]

100. Bonilla, D.A.; Moreno, Y. Molecular and metabolic insights of creatine supplementation on resistance training. Rev. Colomb. Química 2015, 44, 11-18. [CrossRef]

101. Roberts, P.A.; Fox, J.; Peirce, N.; Jones, S.W.; Casey, A.; Greenhaff, P.L. Creatine ingestion augments dietary carbohydrate mediated muscle glycogen supercompensation during the initial $24 \mathrm{~h}$ of recovery following prolonged exhaustive exercise in humans. Amino Acids 2016, 48, 1831-1842. [CrossRef]

102. Myburgh, K.H. Polyphenol supplementation: Benefits for exercise performance or oxidative stress? Sports Med. 2014, 44, S57-S70. [CrossRef]

103. Levers, K.; Dalton, R.; Galvan, E.; O'Connor, A.; Goodenough, C.; Simbo, S.; Mertens-Talcott, S.U.; Rasmussen, C.; Greenwood, M.; Riechman, S.; et al. Effects of powdered Montmorency tart cherry supplementation on acute endurance exercise performance in aerobically trained individuals. J. Int. Soc. Sports Nutr. 2015, 13, 22. [CrossRef]

104. Brown, M.A.; Stevenson, E.J.; Howatson, G. Montmorency tart cherry (Prunus cerasus L.) supplementation accelerates recovery from exercise-induced muscle damage in females. Eur. J. Sport Sci. 2018, 19, 95-102. [CrossRef] [PubMed]

105. Somerville, V.; Bringans, C.; Braakhuis, A. Polyphenols and Performance: A Systematic Review and Meta-Analysis. Sports Med. 2017, 47, 1589-1599. [CrossRef] [PubMed]

106. Bowtell, J.; Kelly, V. Fruit-Derived Polyphenol Supplementation for Athlete Recovery and Performance. Sports Med. 2019, 49, 3-23. [CrossRef] [PubMed]

107. Doma, K.; Gahreman, D.; Connor, J. Fruit supplementation reduces indices of exercise-induced muscle damage: A systematic review and meta-analysis. Eur. J. Sport Sci. 2020, 1-18. [CrossRef]

108. Delecroix, B.; Abaidia, A.E.; Leduc, C.; Dawson, B.; Dupont, G. Curcumin and Piperine Supplementation and Recovery Following Exercise Induced Muscle Damage: A Randomized Controlled Trial. J. Sports Sci. Med. 2017, 16, 147-153.

109. Bonilla, D.A.; Paipilla, A.F.; Marin, E.; Vargas-Molina, S.; Petro, J.L.; Perez-Idarraga, A. Dietary Nitrate from Beetroot Juice for Hypertension: A Systematic Review. Biomolecules 2018, 8, 134. [CrossRef]

110. Siervo, M.; Lara, J.; Ogbonmwan, I.; Mathers, J.C. Inorganic nitrate and beetroot juice supplementation reduces blood pressure in adults: A systematic review and meta-analysis. J. Nutr. 2013, 143, 818-826. [CrossRef]

111. Cuenca, E.; Jodra, P.; Perez-Lopez, A.; Gonzalez-Rodriguez, L.G.; Fernandes da Silva, S.; Veiga-Herreros, P.; Dominguez, R. Effects of Beetroot Juice Supplementation on Performance and Fatigue in a 30-s All-Out Sprint Exercise: A Randomized, Double-Blind Cross-Over Study. Nutrients 2018, 10, 1222. [CrossRef]

112. Mosher, S.L.; Sparks, S.A.; Williams, E.L.; Bentley, D.J.; Mc Naughton, L.R. Ingestion of a Nitric Oxide Enhancing Supplement Improves Resistance Exercise Performance. J. Strength Cond. Res. 2016, 30, 3520-3524. [CrossRef]

113. Clifford, T.; Berntzen, B.; Davison, G.W.; West, D.J.; Howatson, G.; Stevenson, E.J. Effects of Beetroot Juice on Recovery of Muscle Function and Performance between Bouts of Repeated Sprint Exercise. Nutrients 2016, 8, 506. [CrossRef]

114. Clifford, T.; Bell, O.; West, D.J.; Howatson, G.; Stevenson, E.J. The effects of beetroot juice supplementation on indices of muscle damage following eccentric exercise. Eur. J. Appl. Physiol. 2015, 116, 353-362. [CrossRef] [PubMed]

115. Montenegro, C.F.; Kwong, D.A.; Minow, Z.A.; Davis, B.A.; Lozada, C.F.; Casazza, G.A. Betalain-rich concentrate supplementation improves exercise performance and recovery in competitive triathletes. Appl. Physiol. Nutr. Metab. 2017, 42, 166-172. [CrossRef] [PubMed]

116. Wilson, P.B. A Randomized Double-Blind Trial of Ginger Root for Reducing Muscle Soreness and Improving Physical Performance Recovery among Experienced Recreational Distance Runners. J. Diet. Suppl. 2018, 17, 121-132. [CrossRef] [PubMed]

117. Dominguez-Balmaseda, D.; Diez-Vega, I.; Larrosa, M.; San Juan, A.F.; Issaly, N.; Moreno-Pérez, D.; Burgos, S.; Sillero-Quintana, M.; Gonzalez, C.; Bas, A.; et al. Effect of a Blend of Zingiber officinale Roscoe and Bixa orellana L. Herbal Supplement on the Recovery of Delayed-Onset Muscle Soreness Induced by Unaccustomed Eccentric Resistance Training: A Randomized, Triple-Blind, Placebo-Controlled Trial. Front. Physiol. 2020, 11. [CrossRef] 
118. Pu, W.-1.; Zhang, M.-y.; Bai, R.-y.; Sun, L.-k.; Li, W.-h.; Yu, Y.-l.; Zhang, Y.; Song, L.; Wang, Z.-x.; Peng, Y.-f.; et al. Anti-inflammatory effects of Rhodiola rosea L.: A review. Biomed. Pharmacother. 2020, 121. [CrossRef]

119. Tan, L.; Song, X.; Ren, Y.; Wang, M.; Guo, C.; Guo, D.; Gu, Y.; Li, Y.; Cao, Z.; Deng, Y. Anti-inflammatory effects of cordycepin: A review. Phytother. Res. 2020. [CrossRef]

120. Tsai, P.-H.; Lin, F.-C.; Huang, C.-C.; Hou, C.-W.; Cheng, I.-S. Effects of Rhodiola rosea-Cordyceps sinensis Supplementation on Glycogen Synthesis in Exercised Human Skeletal Muscle. Sports Exerc. Res. 2019, 21, 375-386.

121. Choudhary, B.; Shetty, A.; Langade, D.G. Efficacy of Ashwagandha (Withania somnifera [L.] Dunal) in improving cardiorespiratory endurance in healthy athletic adults. Ayu (Int. Q. J. Res. Ayurveda) 2015, 36, 63. [CrossRef]

122. Wankhede, S.; Langade, D.; Joshi, K.; Sinha, S.R.; Bhattacharyya, S. Examining the effect of Withania somnifera supplementation on muscle strength and recovery: A randomized controlled trial. J. Int. Soc. Sports Nutr. 2015, 12. [CrossRef]

123. Ziegenfuss, T.; Kedia, A.; Sandrock, J.; Raub, B.; Kerksick, C.; Lopez, H. Effects of an Aqueous Extract of Withania somnifera on Strength Training Adaptations and Recovery: The STAR Trial. Nutrients 2018, 10, 1807. [CrossRef]

124. Langade, D.; Kanchi, S.; Salve, J.; Debnath, K.; Ambegaokar, D. Efficacy and Safety of Ashwagandha (Withania somnifera) Root Extract in Insomnia and Anxiety: A Double-blind, Randomized, Placebo-controlled Study. Cureus 2019. [CrossRef] [PubMed]

125. Salve, J.; Pate, S.; Debnath, K.; Langade, D. Adaptogenic and Anxiolytic Effects of Ashwagandha Root Extract in Healthy Adults: A Double-blind, Randomized, Placebo-controlled Clinical Study. Cureus 2019. [CrossRef] [PubMed]

126. Singh, N.; Bhalla, M.; De Jager, P.; Gilca, M. An Overview on Ashwagandha: A Rasayana (Rejuvenator) of Ayurveda. Afr. J. Tradit. Complementary Altern. Med. 2011, 8. [CrossRef]

127. Kraemer, W.J.; Ratamess, N.A.; Volek, J.S.; Häkkinen, K.; Rubin, M.R.; French, D.N.; Gómez, A.L.; McGuigan, M.R.; Scheett, T.P.; Newton, R.U.; et al. The effects of amino acid supplementation on hormonal responses to resistance training overreaching. Metab. Clin. Exp. 2006, 55, 282-291. [CrossRef] [PubMed]

128. Fouré, A.; Bendahan, D. Is Branched-Chain Amino Acids Supplementation an Efficient Nutritional Strategy to Alleviate Skeletal Muscle Damage? A Systematic Review. Nutrients 2017, 9, 1047. [CrossRef] [PubMed]

129. Rahimi, M.H.; Shab-Bidar, S.; Mollahosseini, M.; Djafarian, K. Branched-chain amino acid supplementation and exercise-induced muscle damage in exercise recovery: A meta-analysis of randomized clinical trials. Nutrition 2017, 42, 30-36. [CrossRef]

130. Hormoznejad, R.; Zare Javid, A.; Mansoori, A. Effect of BCAA supplementation on central fatigue, energy metabolism substrate and muscle damage to the exercise: A systematic review with meta-analysis. Sport Sci. Health 2019, 15, 265-279. [CrossRef]

131. Fedewa, M.V.; Spencer, S.O.; Williams, T.D.; Becker, Z.E.; Fuqua, C.A. Effect of branched-Chain Amino Acid Supplementation on Muscle Soreness following Exercise: A Meta-Analysis. Int. J. Vitam. Nutr. Res. 2019, 89, 348-356. [CrossRef]

132. VanDusseldorp, T.A.; Escobar, K.A.; Johnson, K.E.; Stratton, M.T.; Moriarty, T.; Cole, N.; McCormick, J.J.; Kerksick, C.M.; Vaughan, R.A.; Dokladny, K.; et al. Effect of Branched-Chain Amino Acid Supplementation on Recovery Following Acute Eccentric Exercise. Nutrients 2018, 10, 1389. [CrossRef]

133. Correia, A.L.M.; de Lima, F.D.; Bottaro, M.; Vieira, A.; da Fonseca, A.C.; Lima, R.M. Pre-exercise $\beta$-hydroxy- $\beta$-methylbutyrate free-acid supplementation improves work capacity recovery: A randomized, double-blinded, placebo-controlled study. Appl. Physiol. Nutr. Metab. 2018, 43, 691-696. [CrossRef]

134. Silva, V.R.; Belozo, F.L.; Micheletti, T.O.; Conrado, M.; Stout, J.R.; Pimentel, G.D.; Gonzalez, A.M. $\beta$-hydroxy- $\beta$-methylbutyrate free acid supplementation may improve recovery and muscle adaptations after resistance training: A systematic review. Nutr. Res. 2017, 45, 1-9. [CrossRef] [PubMed]

135. Rahimi, M.H.; Mohammadi, H.; Eshaghi, H.; Askari, G.; Miraghajani, M. The Effects of Beta-Hydroxy-Beta-Methylbutyrate Supplementation on Recovery Following Exercise-Induced Muscle Damage: A Systematic Review and Meta-Analysis. J. Am. Coll. Nutr. 2018, 37, 640-649. [CrossRef] [PubMed]

136. Rawson, E.S.; Miles, M.P.; Larson-Meyer, D.E. Dietary Supplements for Health, Adaptation, and Recovery in Athletes. Int. J. Sport Nutr. Exerc. Metab. 2018, 28, 188-199. [CrossRef] [PubMed]

137. Ammar, A.; Bailey, S.J.; Chtourou, H.; Trabelsi, K.; Turki, M.; Hökelmann, A.; Souissi, N. Effects of pomegranate supplementation on exercise performance and post-exercise recovery in healthy adults: A systematic review. Br. J. Nutr. 2018, 120, 1201-1216. [CrossRef] [PubMed]

138. Alcantara, J.M.A.; Sanchez-Delgado, G.; Martinez-Tellez, B.; Labayen, I.; Ruiz, J.R. Impact of cow's milk intake on exercise performance and recovery of muscle function: A systematic review. J. Int. Soc. Sports Nutr. 2019, 16. [CrossRef]

139. Amiri, M.; Ghiasvand, R.; Kaviani, M.; Forbes, S.C.; Salehi-Abargouei, A. Chocolate milk for recovery from exercise: A systematic review and meta-analysis of controlled clinical trials. Eur. J. Clin. Nutr. 2018, 73, 835-849. [CrossRef]

140. Vitale, K.C.; Owens, R.; Hopkins, S.R.; Malhotra, A. Sleep Hygiene for Optimizing Recovery in Athletes: Review and Recommendations. Int. J. Sports Med. 2019, 40, 535-543. [CrossRef]

141. Fullagar, H.H.K.; Duffield, R.; Skorski, S.; Coutts, A.J.; Julian, R.; Meyer, T. Sleep and Recovery in Team Sport: Current Sleep-Related Issues Facing Professional Team-Sport Athletes. Int. J. Sports Physiol. Perform. 2015, 10, 950-957. [CrossRef]

142. von Rosen, P.; Frohm, A.; Kottorp, A.; Fridén, C.; Heijne, A. Too little sleep and an unhealthy diet could increase the risk of sustaining a new injury in adolescent elite athletes. Scand. J. Med. Sci. Sports 2017, 27, 1364-1371. [CrossRef]

143. Silva, M.R.G.; Paiva, T. Poor precompetitive sleep habits, nutrients' deficiencies, inappropriate body composition and athletic performance in elite gymnasts. Eur. J. Sport Sci. 2015, 16, 726-735. [CrossRef] 
144. Gupta, L.; Morgan, K.; Gilchrist, S. Does Elite Sport Degrade Sleep Quality? A Systematic Review. Sports Med. 2016, 47, 1317-1333. [CrossRef] [PubMed]

145. Bonnar, D.; Bartel, K.; Kakoschke, N.; Lang, C. Sleep Interventions Designed to Improve Athletic Performance and Recovery: A Systematic Review of Current Approaches. Sports Med. 2018, 48, 683-703. [CrossRef] [PubMed]

146. Peuhkuri, K.; Sihvola, N.; Korpela, R. Diet promotes sleep duration and quality. Nutr. Res. 2012, 32, 309-319. [CrossRef] [PubMed]

147. Doherty, R.; Madigan, S.; Warrington, G.; Ellis, J. Sleep and Nutrition Interactions: Implications for Athletes. Nutrients 2019, 11, 822. [CrossRef]

148. Kim, J. Pre-sleep casein protein ingestion: New paradigm in post-exercise recovery nutrition. Phys. Act. Nutr. 2020, 24, 6-10. [CrossRef]

149. Res, P.T.; Groen, B.; Pennings, B.; Beelen, M.; Wallis, G.A.; Gijsen, A.P.; Senden, J.M.G.; Van Loon, L.J.C. Protein Ingestion before Sleep Improves Postexercise Overnight Recovery. Med. Sci. Sports Exerc. 2012, 44, 1560-1569. [CrossRef]

150. Snijders, T.; Res, P.T.; Smeets, J.S.J.; van Vliet, S.; van Kranenburg, J.; Maase, K.; Kies, A.K.; Verdijk, L.B.; van Loon, L.J.C. Protein Ingestion before Sleep Increases Muscle Mass and Strength Gains during Prolonged Resistance-Type Exercise Training in Healthy Young Men. J. Nutr. 2015, 145, 1178-1184. [CrossRef]

151. Wall, B.T.; Burd, N.A.; Franssen, R.; Gorissen, S.H.M.; Snijders, T.; Senden, J.M.; Gijsen, A.P.; van Loon, L.J.C. Presleep protein ingestion does not compromise the muscle protein synthetic response to protein ingested the following morning. Am. $J$. Physiol.-Endocrinol. Metab. 2016, 311, E964-E973. [CrossRef]

152. Trommelen, J.; Kouw, I.W.K.; Holwerda, A.M.; Snijders, T.; Halson, S.L.; Rollo, I.; Verdijk, L.B.; van Loon, L.J.C. Presleep dietary protein-derived amino acids are incorporated in myofibrillar protein during postexercise overnight recovery. Am. $J$. Physiol.-Endocrinol. Metab. 2018, 314, E457-E467. [CrossRef]

153. Snijders, T.; Trommelen, J.; Kouw, I.W.K.; Holwerda, A.M.; Verdijk, L.B.; van Loon, L.J.C. The Impact of Pre-sleep Protein Ingestion on the Skeletal Muscle Adaptive Response to Exercise in Humans: An Update. Front. Nutr. 2019, 6. [CrossRef]

154. Larsen, M.S.; Clausen, D.; Jørgensen, A.A.; Mikkelsen, U.R.; Hansen, M. Presleep Protein Supplementation Does Not Improve Recovery during Consecutive Days of Intense Endurance Training: A Randomized Controlled Trial. Int. J. Sport Nutr. Exerc. Metab. 2019, 1-9. [CrossRef] [PubMed]

155. Reis, C.E.G.; Loureiro, L.M.R.; Roschel, H.; da Costa, T.H.M. Effects of pre-sleep protein consumption on muscle-related outcomes-A systematic review. J. Sci. Med. Sport 2020. [CrossRef] [PubMed]

156. Deshpande, A.; Irani, N.; Balkrishnan, R.; Benny, I.R. A randomized, double blind, placebo controlled study to evaluate the effects of ashwagandha (Withania somnifera) extract on sleep quality in healthy adults. Sleep Med. 2020, 72, 28-36. [CrossRef] [PubMed]

157. Flynn, S.; Rosales, A.; Hailes, W.; Ruby, B. Males and females exhibit similar muscle glycogen recovery with varied recovery food sources. Eur. J. Appl. Physiol. 2020, 120, 1131-1142. [CrossRef] 